\title{
El mundo árabe y Occidente. La guerra del Golfo
}

\section{INTRODUCCIÓN}

Si desde el surgimiento del islam, al menos, nunca han sido fluidas las relaciones entre el mundo árabe-musulmán y Occidente, debido a conflictos religiosos, políticos y militares, éstas han recobrado máxima actualidad y antagonismo en las últimas décadas, debido sobre todo a la constitución del Estado de Israel y el consiguiente problema palestino, a la revolución del imán Jomeini y, últimamente, a la guerra del Golfo.

Hemos optado por el término Occidente y no cristianismo, porque consideramos que, en las últimas décadas, nuestra cultura secularizada, cualquiera que sea el sentido que se dé al término, no representa valores estrictamente cristianos, aunque hubieran podido serlo en su origen, y que la misma sociedad occidental no se siente plenamente identificada, dentro de su diversidad y pluralismo, por la religión cristiana, ni siquiera por la cultura cristiana. Por eso, ya desde un principio, no creemos correcto ni objetivo considerar el tema de nuestro estudio dentro de un marco de referencia de lucha de religiones, aunque este pudiera haber sido el caso en siglos anteriores.

Por el contrario, sí consideramos válido y objetivo el concepto islam, pues, como veremos, aunque existan muchos elementos e intereses no estrictamente religiosos en las relaciones entre la civilización arábigo-musulmana y Occidente, la cultura islámica e, incluso, la religión islámica representa, si no el único, al menos sí el principal signo y el factor más importante de su identidad y cohesión social nacional y supranacional, máxime en los

momentos de crisis y conflictos. Esto pudiera justificar la más esmerada atención y el mayor recurso que hacemos del Corán respecto a la Biblia que, por otra parte, es mejor conocida en nuestro ambiente cultural. No obstante, 
hemos optado por el concepto mundo árabe por similitud con el de Occidente, y por dejar abierta la puerta a una perspectiva de variables más amplia.

Desde la constitución del Estado de Israel, el 14 de mayo en 1948, el "lobby" sionista ha tenido una enorme influencia sobre los sucesivos Presidentes y Congresos norteamericanos y ha condicionado su política con el mundo árabe. Es poco probable que la Administración de Bush tenga demasiado interés en perder el capital político que sería necesario sacrificar para imponer concesiones efectivas a los israelíes ante los palestinos y naciones árabes circundantes, como pudieran ser territorios por paz. Por otra parte, Israel goza de enorme simpatía entre los formadores de la opinión pública en los medios de Washington, que comparten como un artículo de fe la convicción de que los palestinos deben abandonar a sus líderes "extremistas" (OLP), renunciar a todo derecho sobre el este de Jerusalén, y aceptar "medio pan en vez de ningún pan".

En Israel, el gobierno de Yiithak Shamir, por su parte, si bien atraviesa un momento de alta vulnerabilidad a las presiones estadounidenses, debido a la situación de emergencia financiera que le ha causado la masiva inmigración procedente de la Unión Soviética y Etiopía, ha invitado a un partido reconocidamente racista a participar en el poder, encarceló sin cargos a un moderado líder pacifista palestino y, bajo la dirección del impetuoso Ariel Sharon, ha intensificado sus programas de confiscación de tierras e instalación de nuevos asentamientos judíos en los territorios ocupados. Parece estar dispuesto a pasar una elevada factura por su no respuesta militar a los Scud iraquíes en la guerra del Golfo. Una compleja red de bien fundado temor, neurosis política y fanatismo religioso han tenido paralizado al sistema político israelí durante más de una década.

Los Estados árabes tampoco parecen dispuestos a hacer concesiones en relación con la seguridad de Israel, renunciar a la guerra y aceptarle como un socio que tiene derecho a vivir pacíficamente en la región. Entre otras cosas, porque carecen de un líder al estilo de Sadat.

La guerra del Golfo (17 enero - 28 febrero 1991) para "liberar" a Kuwait de la invasión sufrida por parte de Irak el 2 de agosto de 1990, y a la que dedicaremos amplio espacio en nuestro trabajo, ha servido para hacer aflorar los odios seculares y los agravios, resentimientos, frustraciones y humillaciones, más o menos soterrados, entre árabes e israelíes en primer lugar, y entre los pueblos y cultura arábigo-musulmana y occidental, por extensión.

Nuestra reflexión no será, pues, ni estrictamente religiosa, ni histórica, ni política, sino sociológica y, como tal, incluirá elementos de todos esos campos en la búsqueda de una comprensión de los múltiples factores que motivan, condicionan y distorsionan las mutuas relaciones entre el mundo árabe- 
musulmán y Occidente. Algo similar a lo que A. MacIntire denomina "explicaciones pluralistas".

Ya, desde el primer momento, rehusamos cualquier interpretación del tipo de "razón universal", que establezca una pugna entre el mal y el bien absolutos y que niegue parcelas de razón o razones parciales a las diferentes visiones de la realidad. Por eso nuestro estudio pudiera parecer un sincretismo equidistante y no comprometido. Aun a costa de ello, preferimos la "razón analítica" y el lenguaje de los hechos al lenguaje universalista.

Somos conscientes, por otra parte, de que quienes se encuentran mejor ubicados para comprender, razonar, explicar y ofrecer pistas de solución a los complejos odios y amores entre las dos culturas, son aquellos que participan de ambas cosmovisiones: occidentales que han vivido en "tierras del profeta" y musulmanes que comparten nuestra sociedad. Por otra parte, el mundo árabe-musulmán acusa a los occidentales de haber hecho y escrito su historia con prepotencia y sin contar con ellos. A ellos les daremos, en primer lugar, la palabra.

\section{EL MUNDO ARABO-ISLAMICO}

Los términos árabe y musulmán e islámico no son sinónimos ${ }^{1}$. Son árabes unos 150 millones de personas (algunos hablan de 300 millones) que tienen como idioma oficial, administrativo, literario y cultural la lengua árabe clásica (aunque la población habla mayoritariamente dialectos árabes), que proclaman la arabidad en sus constituciones y que se agrupan en un organismo interestatal llamado Liga de Estados Arabes. Son países árabes: Argelia, Arabia Saudí, Bahrein, Egipto, Jordania, Emiratos Arabes Unidos, Irak, Kuwait, Líbano, Libia, Marruecos, Mauritania, Omán, Palestina, Qatar, Somalia, Sudán, Siria, Túnez, Yemen y Yibuti.

$\mathrm{El}$ árabe conoció una expansión muy rápida gracia a la vertiginosa propagación del islam durante los siglos VII y VIII de nuestra era, en buena parte debido a la "yihad", a la poligamia (sobre todo en Africa), a la elevada natalidad, a los matrimonios mixtos, a la prohibición de cualquier tipo de proselitismo de otras religiones en los países musulmanes y al temor a la pena de muerte aplicada al musulmán apóstata (C 2191). En Egipto, el patriarca ortodoxo copto, el Amba Chenuda, intervino personalmente en el verano de 1977 ante el presidente Anwar es-Sadat para pedir que no se promulgara la ley que incluía la pena de muerte para el musulmán apóstata,

1 Cfr. Lewis, Bernard, El lenguaje político del Islam. Taurus, Madrid 1991. 
pues numerosos coptos que, después de haberse hecho musulmanes para casarse, se arrepintieran de ello, podrían ser ejecutados si volvían a su fe cristiana, como ocurre con frecuencia. Unos años mas tarde esa ley fue promulgada.

El alfabeto árabe, llamado alifato, sirve para escribir también el persa y el urdu, y era también el usado para la lengua turca hasta las reformas de Ataturk en 1920.

Son islámicos (término más usado para conceptos y cosas) o musulmanes (más usado para personas) los "fieles" de la religión islámica, basada en el Corán. Además de las naciones citadas, comprende a: Irán, Afganistán, Indonesia, Niger y las Comodores, con más de un $90 \%$ de población musulmana; Turquía, Malí, Pakistán y Bangla Desh, con más de un 70\%, y otros Estados como la India, Etiopía y los del golfo de Guinea que, aunque con porcentajes menores sobre su población total, aportan muchos millones de fieles al islam. Hay también una gran minoría musulmana en Yugoslavia, en Albania es quizá la religión más importante, y en varias repúblicas soviéticas, como Azerbayán, y en la República Popular China hay importantes núcleos de población musulmana. El islam cuenta hoy con unos 700 millones de fieles (algunos hablan de 900), extendidos desde Al-Andalus hasta el Indostán.

Es imposible comprender la cultura árabe-islámica sin conocer la religión islámica, su historia y la doctrina del Corán 2 , ya que el islam (islam significa sumisión voluntaria y sin reservas del hombre a Dios) es una religión que transciende el ámbito que, hasta el momento de su aparición, se reservaba a las religiones. $\mathrm{Al}$ análisis esquemático y entrelazado de estos tres "items", dedicaremos buena parte de nuestro estudio.

Mientras que el cristianismo, por ejemplo, nació como una minoría perseguida que constituyó su jerarquía dentro de un Estado institucional, legal y socialmente organizado - el romano - el islam fue, además de religión, el Estado y la ley que vino a organizar, además de lo religioso, lo político, lo social, e incluso lo económico, en una sociedad hasta entonces tribal y cláni-

2 Quizá más que una "religión" en el sentido estricto (por lo menos en línea cristiana), Mahoma ha fundado una comunidad social, un tipo peculiar de pueblo: la fidelidad al único Dios, que se identifica con el Dios de las revelaciones anteriores (judías y cristianas), viene a culminar en el surgimiento de una comunidad de fieles, una asociación peculiar de personas fuertemente vinculadas, una "comunidad total" donde se asocian los aspectos exteriores e interiores, políticos, sociales y espirituales, que son los "musulmanes". También los cristianos han formado desde el principio una comunidad de tipo universal, pero en ella falta la concreción social del islamismo: más que una sociedad humana estricta, los seguidores de Jesús acaban formando una comunión espiritual de fe o iglesia. Cfr. FIERro, A., Sobre la religión. Taurus, Madrid 1979; KitagawA, J. M., Religiones orientales. Payot, París 1961, págs. 196-242. 
ca. La identificación de religión y poder queda indeleblemente inscrita en la memoria de los musulmanes, mientras que entre los cristianos, el poder espiritual y temporal, cualquiera que haya sido su interrelación en la historia, han estado siempre comprendidos a través de dos autoridades diferentes: Iglesia y Estado / Dios y César.

Mientras que la antigua civilización greco-romana iba poco a poco asimilando a los invasores llegados del corazón de Europa a las orillas del Mediterráneo, el islam por el contrario asimiló a los pueblos conquistados por él y, excepto en España, la India y los Balcanes, donde su avance fue seguido de un retroceso limitado, les impuso primero su orden social y político, "y aguardó luego las conversiones que no tardaron en llegar" 3.

El Corán es, además del libro sagrado, la fuente fundamental del derecho y de la organización de la sociedad, y Mahoma, junto a profeta, es un hombre de Estado.

La comunidad islámica (Umma) ${ }^{4}$, el conjunto de todos los creyentes unidos por la sumisión a Dios (Islam) se basó en un concepto humano y no territorial, que reclamaba la unidad de sus componentes. El panislamismo, el mahdismo, etc., son movimientos que, muy distintos entre sí, han apelado todos al carácter supranacional y unitario del islam, fuente de identidad y lealtad, máxime en tiempos de crisis. Por eso, en las culturas islámicas no árabes, los letrados estudian árabe y numerosos analfabetos aprenden el Corán de memoria sin comprenderlo. Aunque, al menos teóricamente, está prohibido traducir el Corán, después de muchas discusiones, la mayoría de los teólogos musulmanes han terminado por admitir que las traducciones son legítimas en tanto en cuanto permiten conocer las "ideas" del Corán. De hecho existen dos traducciones del Corán al swahili. Pero, salvo en casos contados 5 , el conjunto de los doctores de la ley prohíbe formalmente todo empleo litúrgico del Corán en traducción.

3 Jomier, Jacques, Para conocer el Islam. Editorial Verbo Divino, Estella 1989, pág.5.

4 En el Corán, sura (capítulo) 3, aleya (versículo) ${ }^{110}$ se dice: "Sois la mejor comunidad humana que jamás șe haya suscitado: ordenáis lo que está bien, prohibís lo que está mal y creéis en Dios. Si la gente de la Escritura creyera, le iría mejor. Hay entre ellos creyentes, pero la mayoría son perversos". Se declara aquí la superioridad religiosa de la comunidad musulmana, no la superioridad étnica de la comunidad árabe.

Todas las citas del Corán están tomadas de la edición preparada por Julio Cortés. Editorial Herder, Barcelona 1986. Las citas las daremos en forma similar a las de la Biblia cristiana.

5 Sólo en el año 1979 la Universidad de El Azhar, de Egipto, se permitió reconocer la "validez canónica" a una versión de Denise Masson, a condición de que reprodujese simultáneamente el texto árabe y se presentara el libro con el título de "Ensayo de interpretación del Corán inimitable". 
Como el islam no tienen sacramentos, el ingreso en esta religión es muy sencillo. Basta recitar la profesión de fe, comúnmente la llamada "sahada": "yo confieso que no hay divinidad fuera de Alá y que Mahoma es el enviado de Dios"; y se legaliza mediante la presencia de dos testigos oficiales.

El islam es una religión revelada. Para el musulmán, el Corán no es una palabra humana, sino la palabra misma de Dios ${ }^{6}$, traída a los hombres por un enviado especial, un Profeta llamado Mahoma 7 . A las palabras personales de Mahoma, el islam les reconoce también un valor muy grande, pero en un plano muy inferior al del Corán; se tienen por inspiradas y su recopilación constituye lo que se denomina hadiz o tradición.

Mahoma fue enviado a los árabes primero y, luego, a toda la humanidad. Después de él no será enviado ningún profeta y la legislación promulgada en el Corán será válida hasta el día de la Resurrección. Con tal perspectiva, el Corán, el don supremo de Dios a la humanidad, se coloca automáticamente en la línea del Evangelio y de la Tora. Puesto que la religión ha sido siempre la misma, las semejanzas o parentescos entre el libro sagrado de los judíos, de los cristianos y de los musulmanes se explican por un mismo origen común, el origen divino. Y las diferencias, más aún las contradicciones, para el musulmán se deben a que los textos de la Tora y el Evangelio han sido mal conservados. En todo caso, el texto coránico está garantizado ${ }^{8}$, y es en él donde el musulmán buscará la enseñanza verdadera de Moisés y de Jesús. No es de extrañar, pues, que en el Corán se encuentren muchos elementos conocidos de Sagrada Escritura: la creación de Adán, el paraiso terrestre, el árbol de fruto prohibido, la desobediencia y expulsión del paraíso, etc. No obstante, en las perspectivas teológicas actuales del islam, no se plantea ningún problema de influjo directo de textos antiguos en su libro sagrado.

El Dios de los musulmanes es el mismo de los judíos y de los cristianos, pues los árabes se consideran descendientes de Ismael, el hijo que Abrahán engendró en su esclava Agar. Y Dios les promete la felicidad si se mantienen fieles, una felicidad relativa aquí abajo y una felicidad absoluta en la otra vida, o bien la gehena caso de que se rebelen. Para los musulmanes, los grandes profetas son Adán, Noé, Abrahán, Moisés, David y Jesús. Mahoma Muhammad - es el sello de la Revelación.

6 C 619 "Este Corán me ha sido revelado para que, por él, os advierta a vosotros y a aquéllos a quienes alcance".

$7 \mathrm{C} 42^{48}$ "Si [los infieles] se apartan, no te hemos mandado para ser su custodio, sino sólo para transmitir". Dios".

8 C 22 "Esta es la Escritura, exenta de dudas, como dirección para los temerosos de 
Mahoma (570-632) nació en La Meca y cuando tenía, según la tradición, unos 40 años, recibe en una cueva del monte Hira una visión en la que el arcángel Gabriel ("Yibril") le ordena que lea lo que luego habían de ser las cinco primeras aleyas de la sura 96 del Corán:

“¡En el nombre de Dios, el Compasivo, el Misericordioso!

1 ¡Recita en el nombre de tu Señor, Que ha creado,

2 ha creado al hombre de sangre coagulada!

3 ¡Recita! Tu Señor es el Munífico,

4 Que ha enseñado el uso del cálamo,

5 ha enseñado al hombre lo que no sabía."

A partir de ahí, el Profeta entrará en trance en muchas ocasiones para recibir las sucesivas revelaciones.

La predicación de Mahoma no era del agrado de los grupos dirigentes de La Meca, dedicados fundamentalmente al comercio, porque se iba ganando a las clases más humildes y, lo que era peor, proclamaba la fe en un Dios único, con el consiguiente descrédito para las divinidades adoradas en la "Ka'aba" 9 -la piedra negra, objeto hoy de veneración de los musulmanes-, cuyos adoradores generaban pingües beneficios a la clase dirigente. Las hostilidades fueron creciendo hasta que Mahoma decidió emigrar a Medina; es la llamada hégira ("hiyra"), que se produce en el año 622 y que marca el año uno del calendario islámico. Volverá a entrar en La Meca hacia el 630 y la muerte le sobrevendrá dos años después, sin nada dispuesto sobre su sucesión, aunque poco antes de morir había confiado a Abu Bakr - el primero de los cuatro califas llamados ortodoxos - la dirección de la oración 10.

A la muerte del califa 'Ali en el 661, el islam había crecido de modo impresionante (Arabia, Palestina, Siria, Mesopotamia, Persia, Egipto, Argelia, Chipre y Rodas), pero estaba dramáticamente dividido. La dinastía omeya llevó el islam hasta la India por Oriente y hasta España por el Occidente; y, siguiendo el modelo de Bizancio, reordenó la organización del Estado dividiéndolo en provincias, estableció la capital en Damasco, puso en marcha una inteligente gestión financiera y fue arabizando (al principio utilizaban la lengua griega) e islamizando la administración y las tierras conquistadas. El descontento social y económico, sobre todo de los esclavos manumitidos por su conversión al islam (los "mawali”) y los conflictos raciales produjeron una auténtica revolución. Con la dinastía 'abbasí en el año 750,

9 Para el Corán, "Abrahán no fue judío ni cristiano, sino que fue hanif, sometido a Dios, no asociador" C $3^{67}$. Es el musulmán perfecto, que edifica la Caaba en La Meca y es el antepasado de la población de esta ciudad por su hijo Ismael.

10 Cfr. AndRAE, Tor, Mahoma. Su vida-su fe. Alianza editorial, Madrid 1987. 
se produce un desplazamiento del centro de poder desde Siria a la zona irania (Irak e Irán), se funda una nueva capital, Bagdad, elementos musulmanes no árabes acceden a los órganos de poder, florece la vida urbana (frente a la más rural y beduina de los omeyas) y se da un notable crecimiento del comercio junto a un crecimiento cultural original. Este brillante panorama duró hasta la segunda mitad del siglo IX en el que el enorme imperio 'abbasí se va convirtiendo en un mosaico de estados independientes en manos de dinastías locales, que mantenían la unidad formal con el califa de Bagdad en función de la mera formalidad de reconocerle "príncipe de los creyentes". El mundo árabe, como tal, desaparece con la llegada de los turcos en el siglo XI.

En la primera mitad de ese siglo (980-1037) muere Avicena, uno de los mayores pensadores árabes, que sistematiza definitivamente los "falasifa" (filosofía) islámicos, y tiene tal influencia en el pensamiento medieval occidental que el francés Ettiene Gilson ha llamado a toda una corriente de la escolástica cristiana "agustinismo avicenizado". San Buenaventura, Alberto Magno, Tomás de Aquino, Duns Escoto, Rogerio Bacon, etc., recibieron el influjo de su pensamiento. En el siglo XII el cordobés Averroes (1126-1198) rompe con la síntesis neoplatónica aviceniana a la que acusa de haber mezclado el pensamiento estrictamente filosófico con las exigencias de la concepción religiosa islámica; reconoce dos niveles de sabiduría, una religiosa y otra exclusivamente científica; elige como único maestro a Aristóteles y se constituye en el máximo representante del aristotelismo medieval y en el "commentator del filósofo". Su pensamiento influye poderosamente la escolástica latina medieval de los siglos XIII y XIV. Y fue la Escuela de Toledo la que tradujo al latín las grandes obras de Avicena y Averroes.

En el campo del Derecho, Averroes establece la distinción entre el poder legislativo y el ejecutivo (500 años antes de nacimiento de Montesquieu). En el siglo XIV el tunecino Ibn Jaldún (1332-1406) desarrolla una interesante teoría sobre la sociedad, afirmando que ésta es un fenómeno natural que se asienta sobre la razón económica y sobre la seguridad, ya que el hombre es el único animal que no puede vivir sin que alguien le gobierne. Inicia así una "sociología" de fuerte base positiva que se anticipa en varios siglos al nacimiento de la sociología en Europa 11.

11 Augusto Compte, el "padre" de la sociología, afirma en su obra "De System of Positive Polity" (Citado en Etzioni, Amitay y Eva (Cop.), Los cambios sociales. Fuentes, tipos y consecuencias. FCE, México 1969, pág.24) que en el siglo XI comienza una nueva época "con la introducción de las ciencias de observación en Europa por los árabes. Para un amplio conocimiento del pensamiento islámico, cfr. CRUz Hernandez, Miguel, Historia del pensamiento en el mundo islámico (2 vols), Alianza Universidad Textos, Madrid 1981. 
Después de la primera guerra mundial, en 1918, van apareciendo los embriones de lo que hoy son los Estados de Oriente Medio ${ }^{12}$.

El problema palestino de hoy es el resultado de la llamada declaración de Balfour (noviembre de 1917), en la que el gobierno británico se mostraba "favorable al establecimiento en Palestina de una patria nacional para el pueblo judío", una tierra en la que no vivía desde hacía casi dos milenios, en perjuicio de quienes habitaban allí ${ }^{13}$, y de la decisión de la Asamblea General de las Naciones Unidas, que el 29 de noviembre de 1947 divide Palestina en dos estados independientes: uno para los judíos y otro para los árabes (EI Estado de Israel se crea el 14 de mayo de 1948, con la Declaración de la Independencia del Estado de Israel, leída por David Ben Gurión). Este era el objetivo buscado desde finales del siglo XIX por la Organización Sionista fundada por Teodoro Herzl, un periodista convencido de que los judíos serían la avanzadilla de la civilización contra la barbarie del mundo árabe. Baste recordar que en 1914 los judíos que vivían en Palestina sumaban 85.000 de una población total de 730.000. Desde ese momento, para los musulmanes "un judío es un perro" ("yahud el calb").

Según los judíos, en el Corán se dice cinco veces que Israel es un pueblo privilegiado por Allah, cinco veces se teje un lazo entre Allah, Israel y la Tierra Santa, e incluso prevé el regreso de las multitudes judías dispersadas a través del mundo ${ }^{14}$. Los líderes musulmanes -siguen afirmando los judíos - al decir: “¡hay que hacer la guerra a Israel, es una cuestión de principios!”, han falsificado el Corán, y lo que necesitan no son misiles, cañones o Scuds sino escuelas y universidades 15 .

Ciertamente en el Corán, respecto a los judíos, se dice: que son hijos de Israel (240.47); que han recibido de Dios signos claros (2211); que tienen un pacto con Dios (283); que Yavé les distinguió entre todos los pueblos (4516); que la Escritura de Moisés es dirección para ellos (3223); que se les envía a Jesús (349); que han recibido Escritura, juicio y profetismo (4516); que son

12 Cfr. Mantran, R., La expansión musulmana. Labor, Barcelona 1982.

13 El libro de Thomas Edward Lawrence (Los siete pilares de la sabiduría, Libertarias. 1990) expone con claridad el incumplimiento de las promesas que el Reino Unido hizo al pueblo árabe, que tanto le ayudó con su rebelión contra el Imperio Otomano.

14 Johnson, Paul, en su obra Historia de los judíos (Trad. de Aníbal Leal). Javier Vergara Editor, Buenos Aires 1991), plantea la tesis de que lo "propio del judaísmo es la convicción de ser el pueblo elegido por el Dios único para realizar una misión trascendente que involucra a toda la humanidad". Aun cuando se rechace el designio divino, los judíos creyeron tan firmemente en su misión especial que llegaron a ser un pueblo especial.

15 Cfr. Rodinson M., Los árabes. Siglo XXI, Madrid 1979. 
destinatarios de la Tierra Santa 16; y se les invita a adherirse al islam (240-103). Pero se les acusa de incredulidad (614), de ignorar y haber alterado la Escritura $\left(2^{75,78}\right)$, y por ello se pide que se les combata "hasta que humillados, paguen el tributo directamente" $\left({ }^{29}\right)$. No obstante, la elección particular del pueblo hebreo apenas tiene cabida en el Corán y, cuando se trata de ella, no es más que un episodio temporal.

Si examinamos brevemente su historia, no parecería debiera existir esa enemistad abismal que separa a judíos y árabes en la actualidad, y que dificulta desde hace décadas las relaciones de todo Occidente, y especialmente, de Estados Unidos con el mundo árabe.

A los judíos les fue, en general, mejor bajo el islam que bajo el cristianismo de los imperios romano-bizantino y romano germánico. Y, como ya había acontecido en Palestina con ocasión de la reconquista árabe llevada a cabo por el sultán Saladino en 1187, los judíos celebraron y apoyaron la conquista árabe de España por los musulmanes en el año 711 - 93 de la era musulmana-, como una liberación. Y de hecho, el judaísmo vivió bajo el Califato de Córdoba (755-1013), una época de esplendor cultural. La convivencia de judíos y musulmanes fue igualmente positiva en el Egipto de los fatimíes ismaelíes durante los siglos XI-XII. Y esto por múltiples razones:

1) Desde un punto de vista religioso, los judíos se hallaban de antemano más próximos de los musulmanes que de los cristianos, debido a su monoteísmo terminante y a los preceptos similares sobre la pureza y los alimentos; de los cristianos se vieron alejados por los dogmas de la Trinidad y de la Encarnación, que se desarrollaron plenamente a partir de los siglos IV-V, y la mariología.

2) El origen semita común y la raíz común de las lenguas árabe y hebreo en su estructura y vocabulario permitió a los judíos utilizar fácilmente el árabe como idioma internacional en el comercio; no así el latín que se limitaba fundamentalmente al clero y a los eruditos. Las lenguas nacionales estaban todavía poco cultivadas.

3) Los judíos fueron útiles al Imperio Islámico en el comercio del Mediterráneo y de Oriente tras la pérdida de la supremacía de los sirios cristianos; en el ámbito cristiano tuvieron que ceder pronto el comercio con el mundo islámico a las ciudades italianas.

4) En el Imperio Islámico había para la minoría judía una base jurídica obligatoria con derechos garantizados, y, al mismo tiempo, autoridades espirituales centrales reconocidas por los musulmanes. En cambio, en la Europa

16 C 521 "¡Pueblo! ¡Entrad en la Tierra Santa que Dios os destinó y no volváis sobre vuestros pasos; si no, regresaréis habiendo perdido!". 
cristiana faltaba, debido a la invasión de los bárbaros, una "praxis" legal obligatoria y las comunidades judías autónomas vivían, desde mucho tiempo antes, sin una autoridad suprarregional. $Y$ en el Oriente cristiano predominaba una legislación antijudía cada vez más dura.

¿De dónde surge, pues, esa enemistad? La respuesta parece estar no en la religión sino en el nacionalismo moderno que ve al sionismo y al islamismo no como comunidades de religión sino como un fenómeno étnico, como "comunidades de pueblo". "Nosotros somos un pueblo, nosotros somos un pueblo", era el lema de Theodor Herzl, y de ahí extrajo la conclusión de que el "pueblo sin tierra necesita una tierra sin pueblo". Pero Palestina no era una "tierra sin pueblo". Allí existía una importante población indígena, constituida en sus seis séptimas partes por árabes. Dos pueblos se enfrentan - el judío y el árabe-palestino -, y ambos tienen la conciencia profundamente enraizada de que esa tierra sólo le pertenece legítimamente a ellos. De aquí la aseveración de Hans Küng: "Judíos y árabes no son enemigos tradicionales, pero sí - hasta hoy - rivales mortales que luchan por la misma tierra" ${ }^{17}$.

Desde la revolución shií de Irán, la sociedad islámica vive traumáticamente la crisis de identidad que supone el choque con Occidente. Lo cultural, lo social, lo político, todas las instancias de la vida de esa civilización están siendo cuestionadas por los valores que van llegando de los países occidentales ${ }^{18}$. En el Islam, a la pobreza se añadẹ el sentimiento de agravio étnico, lo que convierte a la religión, más que en una fe, en un instrumento de venganza; y en el lado occidental, surge un sentimiento equivalente de deshacerse del "moro". Occidente intenta presentar al mundo islámico a la Turquía de Mustafá Kamal Ataturk como el modelo a seguir: el de una democracia progresista basada en el modelo occidental y en la que el islam abandona la vieja teocracia y se convierte en una cuestión de conciencia y no de ley ${ }^{19}$. No obstante, la tendencia religiosa, que no había cesado nunca de existir, recobró en Turquía su vigor, especialmente después de 1960.

17 KÜNG, Hans, Por qué no son enemigos tradicionales, en EL PAIS, 31 octubre 1991.

18 El panislamismo, movimiento nacionalista que defiende la unión de todos los Estados islámicos, surgió como reacción a la penetración europea del siglo XIX. En este mismo siglo se dio un cierto resurgimiento cultural en el mundo árabo-islámico, conocido con el nombre de "Nahda" (Renacimiento), que engendra dos corrientes principales: el modernismo liberal, que trata de conciliar islam y pensamiento moderno y cuyo líder es Rifaat Tahtawi (1801-1873), y el fundamentalismo islámico inspirado por Mahomed Abdo (1849-1905). Actualmente ha tomado ese nombre de "nuevo Nahda" el movimiento islamista de Túnez.

19 G. Beaugé, en su obra Les Capitaux de l'Islam (Presses du CNRS, París 1990) discute ampliamente la cuestión de si el islam, en cuanto civilización teocéntrica cargada de preceptos contra el préstamo usuario en el ámbito de la Umma musulmana, y el capitalismo, siempre ávido de maximizar los beneficios, son compatibles. 
La supresión del califato en 1924 por Ataturk va a suponer la fragmentación de la legitimidad islámica del poder que, de estar centralizado en la institución califal, pasará a repartirse entre los diferentes Estados a continuación de las independencias.

El concepto islámico de legitimidad no se basa en el origen del príncipe, como ocurre en el proceso político occidental, sino en el correcto ejercicio del poder según los imperativos del islam por parte del príncipe, el cual es juzgado por el cuerpo de ulemas quienes, a través de sus "fatwas", dicen lo que es legítimo e ilegítimo. Sadat fue asesinado por ser considerado un apóstata al firmar los acuerdos de Camp David con Israel. Por eso, la legitimidad islámica será cuidada con esmero por todos los regímenes poscoloniales, aun cuando estén calcados en modelo occidentales, en su variante liberal o socialista. Los nuevos regímenes tratarán de "estatalizar" el islam por medio de la subyugación del cuerpo de ulemas e instituciones musulmanas.

El Corán es el libro que contiene la doctrina comunicada por Mahoma a sus seguidores y que él presenta como directamente recibida de "Allah", por eso las citas del Corán van precedidas por fórmulas que indican ese origen divino: “"En el nombre de Dios, el Compasivo, el Misericordioso”. Está divido en 114 suras, y éstas en aleyas.

Mahoma, quien no recurrió a fuentes escritas para su composición - probablemente fue analfabeto - recibió una transmisión oral en árabe de los cristianos y los judíos de su entorno. Así se explican el origen de muchas nociones religiosas que aparecen en el Corán. A la muerte de Mahoma (570632) el Corán no estaba compilado completamente, aunque es posible que estuvieran archivadas las suras de la última época, dictadas a secretarios. La forma de transmisión, hasta entonces, había sido la repetición por parte de Mahoma de las suras hasta que los oyentes las memorizaban y las repetían a coro. La tradición admite que, durante el califato de Abu Bakr, se encargó a un poeta que reuniera los "coranes" conservados por escrito o en la memoria de los recitadores; junto a ésta, hubo en los primeros tiempos del islam otras "colecciones particulares", hasta que el califa 'Utman encargó, hacia el año 650, a Zayd Ibn Tabit, familiar de Mahoma, la redacción de un texto único, que habría de ser la edición canónica del Corán y que es la aceptada por el islam sunní en la actualidad. Hizo falta el trabajo de mucho tiempo para que se realizaran las precisiones necesarias (en consonantes y vocales), y no se obtuvo hasta el siglo IX el texto definitivo. De hecho,, no hubo un solo texto definitivo, sino varios, que se llamaron "lecturas". Se admitieron siete lecturas oficiales en un principio; luego, diez; luego, catorce. Las variantes de esas lecturas y su sentido no difieren gran cosa. 
Se conoce el caso de una aleya que fue aceptada por los musulmanes como auténtica, para ser enseguida suprimida. Se trata de la intercesión de las diosas mencionadas en C 5319-20 20. Durante algún tiempo, los musulmanes admitieron que su "intercesión se esperaba"; luego se dijo que ese inciso no procedía de Dios sino del diablo y fue suprimido. Todos los comentaristas hablan a propósito de C $22^{52}$ sobre la acción del demonio, que enturbia la revelación.

Aunque la redacción del Corán es una confusa miscelánea de difícil clasificación, se suelen dividir las suras, atendiendo a un criterio más o menos cronológico - la supuesta época de composición -, y sin tener en cuenta el orden en que vienen en el libro (así la primera sura por orden cronológico es la 96 del orden canónico), en cuatro grupos: tres períodos correspondientes a La Meca y uno a Medina. El primer período de La Meca corresponde, más o menos, a los primeros años de la vida pública de Mahoma: las frases aquí son cortas, llenas de fuerza, con predicciones escatológicas y con la afirmación de la unicidad de Dios. El segundo período mequí muestra las primeras desilusiones, y se enfrenta a las necesidades primarias de la nueva comunidad naciente. Mientras que el tercero está lleno de leyendas de los profetas anteriores y ocupa una cuarta parte del Corán, el periodo mediní presenta a Mahoma como un Jefe de Estado que dicta sus disposiciones según las circunstancias.

En los primeros períodos, el Corán no subraya ninguna oposición entre la nueva religión y la de los contemporáneos que seguían a Moisés y a Jesús. Al contrario, cita en cierta ocasión a estos últimos para confirmar su propia autoridad 21. Y la orientación de la oración ritual, que se hizo en Medina durante algunos meses después de la hégira hacia Jerusalén, y el ayuno del Ashura, se cambian por la Kaaba de la Meca y el mes de ramadán, sólo cuando los judíos mostraron que no tenían ninguna intención de adoptar el islam.

Para los sunníes, los judíos y los cristianos son puros en sí mismos, pero impuros de hecho porque no se purifican; los "asociadores" ("mosrikim", politeístas) son impuros en sí mismos. Para los shiíes, incluso los๋ cristianos y judíos son impuros en sí mismos. Los sunníes aceptan comer en casa de los cristianos y judíos, con la condición de que los platos que se les presenten no contengan más que alimentos puros. Entre los shiíes, el asunto es más đelicado.

20 "Y ¿qué os parecen al-Lat, al-Uzza y la otra, Manat, la tercera?".

$21 \mathrm{C} 10^{94}$ "Si tiene alguna duda acerca de lo que te hemos revelado, pregunta a quienes, antes de ti, ya leían la Escritura". 
El Corán prevé que "las gentes de la Escritura" pueden seguir ocupando un lugar inferior en el territorio musulmán, con tal que paguen un impuesto especial de protección 22 y se abstengan de cualquier tipo de proselitismo; no obstante, en la Edad Media los "protegidos" se vieron sometidos a ciertas medidas discriminatorias, llevando vestidos de un color especial, no pudiendo montar a caballo, etc.

Indonesia, el país que cuenta con mayor número de musulmanes (unos 200 millones), desde su independencia basó su constitución en los "cinco principios", y los cristianos han gozado de igualdad y libertad. Y la natural tolerancia africana les ha hecho adoptar a algunos Estados del Africa occidental, como Senegal, la cláusula de Estado laico en sus primeras constituciones. Pero cada vez más, los países musulmanes tradicionales (y entre ellos las "petrocracias del Golfo") les incitan a unirse al grupo de los que declaran el islam religión de Estado.

No obstante, el Corán acusa al cristianismo y al judaísmo de haber manipulado sus Escrituras ${ }^{23} \mathrm{y}$, en especial, de haber suprimido los pasajes que anunciaban la venida de Mahoma, ya que el mismo Corán declara que Jesús habló de esa venida ${ }^{24}$. Por eso, Dios encargó a Mahoma que restableciera la religión en toda su pureza. Los musulmanes están convencidos de ser el nuevo pueblo elegido ${ }^{25}$, los únicos verdaderos discípulos de Jesús, que recibió los Evangelios y fue enviado únicamente a los hijos de Israel; y de que el Corán aporta todo lo que es indispensable saber sobre Jesús ${ }^{26}$. Por eso, convertirse al cristianismo carece de sentido para los musulmanes: es una regresión.

Los musulmanes conceden una gran atención al orden histórico y cronológico de las suras. Esto importa mucho en el derecho islámico porque, habiendo cambiado la legislación coránica en algunos puntos en vida aún de Mahoma, una aleya puede abrogar otras aleyas más antiguas. La última aleya de una serie de ellas será la que haga ley.

22 C 929.

23 C 515 “ ¡Gente de la Escritura! Nuestro Enviado ha venido a vosotros, aclarándoos mucho de lo que de la Escritura habíais ocultado y revocando mucho también. Os ha venido de Dios una Luz, una Escritura clara".

24 C 616 "Y cuando Jesús, hijo de María, dijo: “¡Hijos de Israel! Yo soy el que Dios os ha enviado, en confirmación de la Tora anterior a mí, y como anuncio de un Enviado que vendrá después de mí, llamado Ahmad..."

25 C 2455 "A quienes de vosotros crean y obren bien, Dios les ha prometido que ha de hacerles sucesores en la tierra, como ya había hecho con sus antecesores..."

26 Cf. ImBaCH, Josef, ¿De quién es Jesús? Su significación para judios, cristianos y musulmanes. Herder, Barcelona 1991. 
En el texto oficial del Corán, siguiendo una costumbre bien conocida en la literatura religiosa, las suras están clasificadas según una longitud decreciente, siendo la más larga la sura 2. La primera sura o "Fatiha", "la que abre", tiene que ponerse aparte. Los musulmanes la recitan sin cesar como oración y desempeña entre ellos el papel del padrenuestro entre los cristianos 27 .

En el Corán se repite incansablemente la idea de Dios único, creador, todopoderoso, sabio, misericordioso (no admite nada parecido a una idea trinitaria de la divinidad y rechazan la encarnación 28 hasta el punto de que quizá sea ésta, junto a la resurrección de los muertos, la doctrina más importante de la fe islámica: "Di : ¡El es Dios, Uno, Dios, el Eterno. No ha engendrado, ni ha sido engendrado. No tiene par”. “¿Quién dará vida a los huesos, estando podridos?. Di: les dará vida Quien los creo una vez primera - El conoce bien toda creación" ${ }^{29}$. El islam es la religión del "tawhid", de la proclamación de la unicidad divina. Dios se encuentra demasiado lejos para presentarse preferentemente como "padre de los hombres": por eso se revela más bien como señor y guía de la historia.

Jesús es un gran profeta - mayor que los otros -, a quien llama Mesías, Espíritu de Allah y Verbo ${ }^{30}$, y acepta su nacimiento de una virgen. De hecho hay mezquitas dedicadas a María ${ }^{31}$, que es la única mujer que se menciona expresamente con su nombre en el Corán; a todas las demás se las designa por el nombre de su marido: la mujer de Adán, la mujer de Noé...

La fe musulmana hace entrar al fiel en una sociedad en la que goza de un estatuto religioso igualitario, ya que el islam no supone ningún sacerdocio, aun cuando comprenda de hecho una clase de clérigos, hombres de religión, a los que su saber distingue de los demás. Entre los shiíes existe la tendencia a atribuir ciertas cualidades especiales de sacralidad a los líderes de sus comunidades 32 .

27 C 11-7 “ ¡En el nombre de Dios, el Compasivo, el Misericordioso! Alabado sea Dios, Señor del universo, el Compasivo el Misericordioso, Dueño del día del Juicio. A Ti solo servimos y a Ti solo imploramos ayuda. Dirígenos por la vía recta, la vía de los que Tú has agraciado, no de los que han incurrido en la ira, ni de los extraviados".

28 C 4171 “ ¡Gente de la Escritura!(...) ¡No digáis Tres! ¡Basta ya, será mejor para vosotros! Dios es sólo un Dios Uno..."

29 C $112^{1-4} ; 36^{78-79 .}$

30 Cfr. Bucaille, Maurice, La Biblia, el Corán y la ciencia. Arias Montano Editores, Madrid 1990.

31 C 6612 "Y a María, hija de Imran, que conservó su virginidad y en la que infundimos de Nuestro Espíritu. Tuvo por auténticas las palabras y Escrituras de su Señor y fue de las devotas".

32 Para el tema de las relaciones entre el islam y el judeocristianismo cfr. KüNG, H., El cristianismo y las grandes religiones. Cristiandad, Madrid 1987, págs. 142-167. 
Además, la religión islámica abarca también la legislación positiva de los países musulmanes. La primera fuente de la ley islámica - la "saría" - es el Corán; le sigue la tradición (costumbre) - "sunna". 33, de donde viene sunní, que designa al islam mayoritario frente a las sectas, como los shiíes -, que se transmite a través de unas narraciones llamadas hadices (acontecimientos) ${ }^{34}$, cuya veracidad será mayor cuanto más cercano al Profeta sea el primero que la relató. Los hadices suelen estar construidos según este esquema o uno similar: "Me contó Fulano que le había relatado Mengano que Zutano... que Perengano vio al Profeta, ensálcele y sálvele Allah, que...". Esta fuente de derecho se quedó pequeña cuando la comunidad de fieles - la "umma" - creció al vertiginoso ritmo que lo hizo. La deducción por analogía y el consenso entre los jurisconsultos ("Iytihad") ${ }^{35}$ se incorporan pronto como fuentes para la legislación y la administración de justicia. No obstante, aún hoy, muchos países proclaman en sus constituciones que su legislación emana directamente del Corán.

A la "sarí'a" pertenecen disposiciones tales como el velo de las mujeres, el cortar la mano al ladrón, la prohibición de bebidas alcohólicas, la prohibición de préstamos con interés, la ejecución del musulmán que apostata, etc., que se siguen observando en las naciones donde el poder es tradicional (como Arabia Saudí) y que los fundamentalistas exigen vuelvan a ponerse en vigor donde han sido abandonadas 36 .

Los deberes fundamentales de un musulmán se sintetizan en "los cinco pilares del islam", que obligan a título individual a todos los musulmanes después de la pubertad y en las condiciones requeridas para estar sometidos a la ley: la profesión de fe, la oración, la limosna, el ayuno y la peregrinación.

La "shahada", o profesión de fe, consiste en la recitación de la fórmula requerida, necesaria y suficiente para ser considerado ante la ley como miembro de la comunidad islámica: "no hay dios más que Dios y Mahoma es el Profeta de Dios", que en árabe es una sonora aliteración: "la ilaha illa Allaha wa Muhammadu rasuli Allah". El testimonio a favor de la unicidad divina ayuda a negar la sumisión a las autoridades que van en contra del ximos.

33 "Sunna" designa la recensión de los actos de Mahoma y de sus compañeros más pró-

34 Hadiz (hadices) son las narraciones que los compañeros de Mahoma dejaron sobre su vida. Su conjunto constituye la sunna.

35 "Iytihad" significa el esfuerzo personal de interpretación para adaptar los preceptos coránicos a la evolución de las sociedades.

36 Cfr. C 2431; 3359; 2191. 
Corán y en contra del islam. Durante el período de ocupación colonial, esta actitud ha fomentado los movimientos de resistencia nacional a través de una resistencia cultural. La fórmula "Allahu Akbar” (sólo Dios es grande) fue el grito de guerra de los ejércitos mulsumanes.

Son cinco las oraciones rituales ("salat") diarias prescritas por la ley: al alba ("subh"); la oración del mediodía ("zuhr"); la oración de la tarde (" "asr"); la oración del ocaso ("magrib"); y la oración de la noche (" ishà"). La oración del viernes al mediodía tiene una solemnidad especial y se celebra con los fieles reunidos en la mezquita. El muecín (almuédano) es el encargado de invitar al rezo desde el minarete (modernamente suele hacerse por megafonía, e, incluso, por radio). Además, existe una oración especial para cada una de las dos grandes fiestas del año (final de ayuno del ramadán y sacrificios de la peregrinación) y otras oraciones para diversas ocasiones (funerales, calamidad pública, etc.). La oración privada obliga igualmente a hombres y mujeres y debe realizarse en estado de pureza legal. Las menstruaciones, por ejemplo, apartan temporalmente a las mujeres de la oración ritual. El canto siempre es en árabe. "Cuando Turquía quiso imponer la lengua turca para esta observancia, chocó con una resistencia obstinada y hubo de renunciar a la innovación después de algunos años" ${ }^{37}$.

La "zakat" (de donde la palabra castellana azaque) o limosna legal empezó siendo la tasa que se pagaba para el socorro de los más necesitados, y terminó por convertirse en un impuesto sobre el patrimonio exigido sólo a los musulmanes. Incluso hoy, cuando los estados musulmanes modernos recurren a métodos tributarios occidentales, los creyentes piadosos siguen "purificando" sus bienes entregando, aproximadamente el 2,5\% de ellos, como limosna para fines religiosos y de beneficencia. La "zakat" no tenía que servir más que para los musulmanes o para el islam, y sólo la limosna del ramadán puede destinarse a los no musulmanes. Varias aleyas del Corán enumeran a los posibles beneficiarios: "Las limosnas son sólo para los necesitados, los pobres, los limosneros, aquéllos cuya voluntad hay que captar, los cautivos, los insolventes, la causa de Dios y el viajero. Es un deber impuesto por Dios. Dios es omnisciente, sabio" ${ }^{38}$. La "zakat" no suprime la limosna privada, sino que la completa. Representa por tanto, el aspecto de estructura financiera de la sociedad musulmana primitiva. Aun afirmando que sigue intangible el derecho de propiedad privada, en la época de los socialismos, los teóricos del islam se apoyan en la limosna legal para justifi-

37 JOMIER, Jacques, Para conocer el islam. Editorial Verbo Divino. Estella 1989, págs. 57.

38 C 960. 
car la intervención del Estado o de la colectividad en la distribución de las riquezas.

La esencia del ayuno del mes de ramadán, el noveno del año lunar musulmán, obligatorio deşde los 12 años, está en abstenerse de toda clase de alimentos, bebidas, tabaco, perfumes y relaciones sexuales durante todo el día: “(...) Comed y bebed hasta que, a la alborada, pueda distinguirse un hilo blanco de un hilo negro. Luego observad un ayuno riguroso hasta la caída de la noche (...)" 39 . El ayuno y la piedad diurnos dan paso a una noche extraordinariamente festiva, con el consiguiente aumento del consumo de alimentos, carburante y electricidad. Sin duda que el estado letárgico del mes del ramadán influyen en una caída de la productividad, compensada en algunas naciones por la mano de obra extranjera que sí trabaja a pleno rendimiento. Pero este enfoque racional-economicista es tachado de "irreverente" tanto en medios religiosos como oficiales: "se trata de un tema espiritual y por lo tanto, no se puede abordar desde una perspectiva material". Voces árabes autorizadas, por otra parte, han recordado que Occidente tiene sus vacaciones pagadas durante las cuales se frena el trabajo industrial.

El artículo 222 del Código Penal marroquí estipula que todo musulmán, notoriamente conocido como tal, que rompe públicamente el ayuno, puede ser condenado hasta a seis meses de cárcel. En Occidente, algunas empresas sí facilitan locales para las plegarias rituales de sus trabajadores musulmanes practicantes, siempre y cuando éstas se celebren en las horas de la comida o en la pausas laborales reglamentarias. Pero en la práctica del ramadán "no se benefician de ninguna medida particular". En algunas naciones, como Francia, la observancia del ramadán gana adeptos de año en año. Mahomed Arkun, profesor de la Sorbona, lo explica más por motivos de "búsqueda de identidad" que por razones "estrictamente religiosas".

La obligación de peregrinar a La Meca ("hayy"), al menos una vez en la vida, incumbe a todo musulmán adulto y sano si las circunstancias de su fortuna y otras, como camino seguro, independientes de su voluntad, no se lo impiden. Desde la perspectiva religiosa, la peregrinación es un gran "perdón" que, si está bien hecha, alcanza la remisión de todos los pecados anteriores, y sirve para unificar el dogma y la prácticas religiosas. En la peregrinación hay también un sacrificio, el único oficial en el islam, y las prohibiciones sexuales deben ser observadas mientras se está en estado de sacralización (vestido con el "ihram"). Desde el punto de vista sociológico, esas inmensas reuniones (dos millones en 1985) les hacen tomar conciencia 
de la fuerza del islam, de la multiplicidad de pueblos que lo han abrazado y de los lugares históricos donde se inició. Sin serlo oficialmente, el peregrino se siente el representante de los parientes y amigos.

Hasta comienzos del siglo XIX, cuando se introdujo la navegación a vapor, la peregrinación era también la ocasión para una feria comercial considerable en la ruta comercial de la India al Mediterráneo, "y las transacciones que entonces se efectuaban en el espacio de dos o tres semanas alcanzaban en el siglo XV un volumen calculado en dos millones de monedas de oro" ${ }^{40}$.

En la práctica, la mayoría de los musulmanes mueren sin haber peregrinado ${ }^{41}$.

El Corán de los últimos períodos contiene insultos y maldiciones contra los cristianos y, especialmente, contra los judíos. Y también contiene incitaciones a la violencia y a prácticas que hoy parecen inhumanas. Pero sería tan injusto identificar el islam con la violencia y el antisemitismo, como identificar el cristianismo con el césaro-papismo, la inquisición, el antisemitismo y los abusos coloniales ${ }^{42}$.

El antropólogo Julio Caro Baroja ha planteado la explicación de la violencia en las religiones abrahámicas como resultado de que las tres religiones son monoteístas, dogmáticas y, por tanto, se sienten poseedoras de la verdad y se excluyen mutuamente. Esto parece ser cierto en la medida en que las religiones se cierren en un institucionalismo integrista, defensor de la propia identidad; en la normativa, en la ley, en lo que las distingue y, por tanto, en lo que las separa. Pero esto podría considerarse la "cáscara de la religión". Cada religión, si quiere dialogar con las otras, debe aceptar que habla del absoluto, del "totaliter alter", pero sin poseerlo.

Las religiones, por ser algo muy importante y profundo en la vida de los hombres, pueden ser ambiguas y peligrosas, pueden crear condiciones de paz o conducir incluso a la guerra. Cuando las religiones, como cualquier otra institución, se convierten en ideología, incluida la agnóstica y la atea, acaban siendo instrumentos peligrosos para el individuo y para la sociedad y pueden desembocar en la guerra y la violencia. En nombre de la tecnociencia, que

40 JOMIER, Jacques, op.,cit., pág.68.

41 Cfr. Moreno, Juan Francisco, Lo árabe y lo islámico, un primer acercamiento, en L.E.A. (La Escuela Agustiniana) No37,octubre-diciembre 1990, pp.26-33.

42 J. Attali en su obra Milenio (Seix Barral 1991), afirma que "a partir de las primeras formaciones sociales sedentarias - o sea, diez mil años antes de nuestra era - tres poderes se organizan para canalizar y administrar la violencia, tres poderes que encajan jerárquicamente uno en el otro: el religioso, el militar y el económico. El primero administra las relaciones con el más allá". 
permite la destrucción de la biosfera o la manipulación genética, y en nombre de la defensa del hombre, se han cometido en nuestro siglo masacres y barbaridades como ninguna religión había realizado antes.

No obstante, en líneas generales, creemos que podemos afirmar, que mientras los movimientos de reislamización, e incluso de rejudaización, no han dudado en rechazar la democracia y acudir a la violencia terrorista, los movimientos integristas cristianos han aceptado la democracia y la dualidad Iglesia-Estado.

Por esto, no considero compartible la opinión del traductor del Corán y arabista argelino, afincado en Francia, Jacques Berque, cuando afirma que el Corán es compatible con la democracia, el progreso y los derechos humanos, ya que "en términos estrictamente coránicos la consulta de todos los seres humanos y no sólo de los notables y los ricos es el sistema preferencial de gobierno". De lo anotado y de nuestro estudio posterior parece quedar claro, que el sistema político preconizado por el Corán tiende abiertamente hacia una teocracia; su "profecía ética" no ha conducido a una racionalidad típica de Occidente que le ha llevado a un elevado progreso económico, como ha demostrado, entre otros, Max Weber; y ciertas prácticas, incluso actuales en los países tradicionalmente islámicos, están en abierta contradicción con los derechos humanos, tal como han sido formulados por las Naciones Unidas.

Ciertamente que puede sostenerse que "del Corán como de los Evangelios o la Tora, pueden hacerse lecturas racionales o retrógadas, y también lecturas de evasión, lecturas místicas o lecturas puramente literarias. Yo -afirma el señor Berque- reivindico una lectura racional”. Pero, al menos desde la sociología de la religión, el problema no es la lectura que pueda hacerse o la que uno quiera hacer, sino aquella que se contiene en el Corán, sobre todo teniendo en cuenta la "revelación literalista" que preconiza e, incluso, más aún, aquella que han hecho los musulmanes a través de la historia y sobre la que han fundamentado su tipo de sociedad característica. Tampoco es suficiente con aseverar que en "sus 6.232 versículos la palabra "razón" es pronunciada 44 veces, mientras que la raíz "sagrado" sólo aparece siete veces". Hay muchos tipos de razón y de racionalidad, de sagrado y de sacralidad. Una cosa es la "inspiración" y otra la "revelación literal" por parte de Dios a Mahoma, que convierte al Corán en "copia idéntica de la escritura divina". En esta distinción pudiera fundamentarse la diferenciación entre fundamentalismo del libro, el Corán, e integrismo de la Iglesia, señora del "depositum fidei".

Por lo mismo, creemos que tampoco se puede aseverar, sin matices, que “el integrismo musulmán es una interpretación tendenciosa y fascistoide del 
islam" o que "el integrismo es toda una desviación del islam" ${ }^{43}$. Ciertamente que pudiera ser que nuestra sociedad occidental - como afirma Jean Baudrillard 44 -, practique "el integrismo democrático blando, sutil y vergonzante, el del.consenso (...) (el de las Luces, de los Derechos del hombre, de la izquierda al poder, del intelectual arrepentido, del humanismo sentimental) tan feroz como el de cualquier religión tribal o sociedad primitiva".

En todo caso, nos encontraríamos con dos tipos de integrismos: el "hard" y el "soft". De todas formas, parece claro que estamos ante un proceso de reislamización, y ya no sólo en tierra del islam, sino en los islotes coránicos de la Europa desarrollada, primero como mecanismo de defensa con el mundo de los infieles, y, segundo, como medio de construcción de una sociedad que posibilite la refundación teocrática. El fracaso de seculares tentativas de recuperar el tiempo perdido, con su punto culminante en la derrota ante Israel en la guerra de 1967 , hace que la opción no sea ya la de modernizar el islam sino la de islamizar la modernidad.

\section{LOS CISMAS Y LAS SECTAS EN EL ISLAM}

En el surgimiento de cismas y sectas en el islam, como en otras religiones, existen factores religiosos e históricos. Una de las sectas más importantes es la "shí'a" (partidario-secta) que nace, entre otras causas, de un problema sucesorio. En el año 657, el cuarto califa, 'Ali, yerno de Mahoma, hubo de recurrir a las armas para afianzar su autoridad, pero fue derrotado y asesinado junto a su hijo Husayn por los seguidores de Mu'awiyya. Los que se adhirieron a éste y, a continuación, a los califas que le sucedieron, son los sunníes (mayoría-ortodoxia) o gentes de la "tradición". Para ellos, el califa debía ser escogido normalmente entre los descendientes de la tribu árabe de Quraysh, la de Mahoma. Representan actualmente el 90\% del conjunto de los musulmanes.

Los defensores de que el Corán contenía pasajes, maliciosamente omitidos en la edición del califa 'Utman, en los que se establecían los derechos

43 BERQUE, Jacques, El integrismo es toda una desviación del islám, en EL PAIS, 9-41991 (entrevista concedida a Javier Valenzuela).

44 BAudrillard, Jean, La guerra del Golfo no ha tenido lugar. Editorial Anagrama 1991. Esta es su tesis: Al no haber enemigo capaz de resistir y de reaccionar, no pudo haber guerra; una guerra ganada de antemano no es una guerra. La tesis no es tan clara, pues, a excepción de Kuwait, todas la guerras en las que intervinieron fuerzas europeas y americanas en el Tercer Mundo acabaron en tragedias: Indochina, Argelia, Vietnam, Corea, Afganistán... 
hereditarios y exclusivos de 'Alí (cuarto califa de los sunníes y primer imán de los shiíes) y sus descendientes a regir la comunidad de fieles, son los shiíes, que están fuertemente apegados a la tradición más ortodoxa - casi rigorista- y han acentuado el carácter religioso de sus reivindicaciones. La "shí'a" se ha convertido desde entonces en minoría sociopolítica del islam con todo lo que ello ha supuesto de marginación, subversión y esoterismo. Son actualmente el $10 \%$ de los musulmanes.

En este sentido, el triunfo de la República islámica iraní, lograda por el islam shií duodecimano, ha significado una cierta revancha histórica de la minoría frente a la mayoría, de una legitimidad frente a la otra, frente al islam sunní, mayoritario y oficial en todos los demás países árabes. No obstante, no se puede asimilar fundamentalismo con shiísmo, porque muchos fundamentalistas son sunníes.

El grupo de los neutrales en la separación entre sunníes y shiíes reciben el nombre de "mu'tazila". Esto son los auténticos creadores de la teología racional musulmana y los que, mediante la utilización de la dialéctica, abrieron las puertas al uso de la filosofía helénica.

La Shí'a, a su vez, está también dividida: shiíes duodecimanos (reconocen doce imanes), musta'li, bohoras; ismailíes (reconoce siete imanes), nizari, Aga Kan, etc. Una de sus escisiones la constituyen los drusos, extraña secta hermética que no hace propaganda y que rehúsa nuevos prosélitos. Hoy se extiende en zonas de Siria y Líbano 45 . Existe también el "mahdismo", un movimiento mesiánico que espera que el "mahdj" baje a la tierra un día antes del juicio final.

Hay también musulmanes preocupados por la interiorización y la expresión más sensible de su fe, más allá del seguimiento ritual de las plegarias obligatorias y de la mentalidad jurídica, y que entran en el campo de la mística, del esoterismo y de la experiencia religiosa. Los juristas estrictos dicen que el hombre no puede amar a Dios en sí mismo, sino solamente su ley, su servicio, su voluntad. Pero muchos místicos fundamentan su fe en la presencia de Dios, no tan íntima como la presencia de Dios en el cristianismo, sino la de un señor amado cuyas exigencias se compaginan con una bondad inmensa con quien le obedece. Bastaría citar la frase de la mística Rabi'a: "Voy a apagar el infierno y a incendiar el paraíso para que Dios sea adorado y amado sólo por él y no por sus recompensas". Este movimiento recibe el nombre de "sufismo" ("suf", lana) en recuerdo de los hábitos que llevaban los primeros sufíes a imitación de los monjes cristianos o de otras reli-

45- Cfr. VARIOS, El Islam (2 vols.). Siglo XXI, Madrid 1987. 
giones. Se negaron a abandonar el ideal de austeridad de los primeros años, y rechazaron la vida fácil de sus correligionarios enriquecidos con los botines de la conquista ya en tiempos de Mahoma.

Adoptan prácticas colectivas de piedad en las cofradías populares y siguen las enseñanzas de los grandes maestros espirituales. Poseen muchas veces, incluso hoy, un documento o cadena de iniciación que menciona cuál fue el maestro que los inició, el maestro de ese maestro, y así sucesivamente, remontándose hasta Mahoma, pero pasando, en la mayor parte de los casos, por Hassán al-Basrí 46. Muchos de ellos repiten fórmulas, oraciones jaculatorias, contándolas con sus rosarios, que les sirven para vivir en la presencia de Dios.

Pero sufismo no se opone sistemáticamente a activismo, ya que ha habido sufíes comprometidos en la acción política, como Osmán Dan Fodio, fundador del imperio Sokoto, en el siglo XIX.

Muchos místicos famosos, como Ibn ' Arabi (nacido en Murcia en 1165), Nabulsí en Siria, Abd al-Qader al-Jilani en Irak, etc., crearon cofradías que tienen sus seguidores extendidos por muchos países y han contribuido a la expansión del islam, sobre todo en.Africa. Algunos estudios recientes consideran a las cofradías como un islam paralelo al islam oficial.

Cuando llegaron los árabes a la Península Ibérica en el año 711, su doctrina religiosa venía ya influenciada por elementos místicos tomados del neoplatonismo alejandrino, del misticismo hindú y persa, del monacato oriental y del eremitismo cristiano. Tenían en gran estima la soledad y hablaban del matrimonio espiritual. Ascetas y místicos sufíes poblaron la España musulmana. Su influjo en Ramón Llull, santa Teresa de Avila, san Juan de la Cruz, san Ignacio de Loyola y fray Luis de León parece estar probado.

Existen también movimientos, como el "babista" y el "baha'ista" surgidos en el siglo XIX que, aunque han surgido del islam, ya no pueden ser considerados como musulmanes porque se presentan como nuevas religiones destinadas a sustituir al islam. Los primeros son pocos y los "baha'istas", además de ofrecer un sincretismo de las religiones anteriores, utilizan las grandes palabras de moda: dicen ser la religión científica, antidogmática; luchar por la igualdad de género humano, la igualdad del hombre y de la mujer, la paz del mundo, etc.

46 De entre los teóricos de la vida espiritual, destaca en el siglo XII, el tratado del imán al-Ghazali (al que los escolásticos latinos llamaban Algazel) titulado La reviviscencia de las ciencias de la religión. 


\section{EL FUNDAMENTALISMO ISLAMICO}

El fundamentalismo islámico, en su aspecto religioso, se atiene a una lectura literal del Corán, sin admitir la más mínima crítica histórico-científica del texto transmitido a través de las generaciones, sin dar cabida a una lectura que tenga en cuenta los "géneros literarios" propios de la época en que se redacta el Libro Sagrado y, sobre todo, sin permitir lo más mínimo la armonización o concordancia de principios doctrinales que, a veces, se muestran contradictorios. El Corán ha de ser aceptado tal cual, sin exégesis ni hermenéutica. Además, los fundamentalistas propician la imposición del orden islámico en todo el mundo, musulmán y no musulmán, porque dicho orden está dictado verbalmente por el mismo Dios.

Del más rígido literalismo se pasa pronto al más rígido legalismo. Los fundamentalistas se acercan al Corán como si éste fuese un código o ley que ha de regular hasta los más mínimos detalles de la vida individual y social del creyente ${ }^{47}$.

De resultas de todo ello, el Islam no acaba de resolver en síntesis eficaz el binomio identidad islámica y progreso; o el de fe y razón; o el de autenticidad y modernidad.

En Occidente existe la convicción generalizada de que el fundamentalismo islámico es la expresión exterior de la revolución iraní de 1975 48. Sin embargo los expertos coinciden en situarlo en los años 1920 y, algunos como Roger Garaudy, afirman que es una criatura más, "una consecuencia del colonialismo" europeo. Por el contrario, sociólogos como Alain Touraine, aseguran que "hay que estar ciegos para ver en este período la prolongación de los movimientos de liberación colonial".

En 1927-1928 un maestro egipcio, Hassan Al-Banna fundó en Ismailía una asociación medio religiosa medio política, en la que sus miembros rechazaban "esta vida de humillación y esclavitud" , juraban obediencia a Dios, se convertían en "soldados del mensaje del islam" y combatían la presencia británica en Egippto. En la década de los 40, Al-Banna empezó a perder el contrỏ de su organización, los Hermanos Musulmanes, y sus elementos más radicales recurrieron a la violencia.

Hacia 1954, uno de los afiliados a los Hermanos Musulmanes, Sayyid Qutb empezó a relacionar la sociedad con el Islam y a denunciar el olvido de los valores religiosos; creó el concepto de "comunidad musulmana"

47 Cf. KHoury, Adel-Th., Los fundamentos del islam. Herder, Barcelona 1991.

$48 \mathrm{El}$ año 1979 marca el comienzo del siglo XV de la era hegiriana. 
("umma"), es decir, "un conjunto de musulmanes que viven de acuerdo con los principios islámicos" con exclusión de los "autodenominados musulmanes", que sólo cumplen algunos preceptos del Corán. Los verdaderos creyentes deben apartarse de la sociedad no creyente, vivir aislados y combatir a la sociedad impía y a sus dirigentes. Se trata de un retorno a las fuentes para llevar a cabo la retradicionalización de la sociedad islámica. La represión de los gobiernos norteafricanos contra los Hermanos Musulmanes llega hasta nuestros días.

Para muchos expertos, como Bruno Etienne, el fundamentalismo islámico es la forma político-religiosa que toma la ortodoxia musulmana enfrentada a los problemas de la modernidad. El laicismo (y la modernidad) son consecuencia del principio gestado en el siglo XIV de la historia occidental, que establecía que la religación de la criatura con el Creador era fundamentalmente un asunto privado y no público.

En el mundo árabe fueron fracasando las soluciones liberales, el reformismo islámico, el socialismo árabe, especialmente en su vertiente nacionalista o nasserista (panarábica), dejando paso al integrismo durante las dos últimas décadas. El declive del nasserismo trasladará el liderazgo árabe de Egipto a Arabia Saudí y abrirá la vía a la retradicionalización islámica que la revolución iraní reforzará en 1979.

Quizá los dirigentes árabes se han olvidado de que el verdadero nacionalismo consiste en asociar justicia social, libertad política y crecimiento económico.

En múltiples países del mundo, el nacionalismo ha tomado desde hace un siglo la forma de "bismarckismo", es decir, ha permitido, a partir de un Estado autoritario, crear una "sociedad civil" fuerte y diferenciada. Tal fue el caso, después de Alemania, de Italia y Japón, en la segunda mitad del siglo XIX. Y probablemente sea hoy también el caso del país musulmán más grande, Indonesia, (que tiene el mismo número de fieles al Corán que la totalidad de los países árabes). Pero en el mundo árabe musulmán hemos asistido a una evolución opuesta: el Estado ha devorado a la sociedad.

Con frecuencia en el mundo árabo-islámico se acusa a Occidente de tener una visión monopolista, descalificadora, arrogante y abusiva del islam, y reivindica su derecho a elaborar su "propio relato sobre su propia historia, sustituyendo el que Occidente había conformado" 49. De aquí nuestros interés en conocer de primera mano la visión que de su historia

49 Cfr. SAID, Edward W., Orientalismo. Libertarias, Madrid 1990.

También el marroquí A. Laroui, en su obra Histoire du Maghreb (1970), y el tunecino H. Djaït en La personalité et le devenir arabo-islamique (París 1974) ponen en práctica la revisión crítica de las interpretaciones establecidas "desde fuera". 
tienen pensadores musulmanes significativos que están en contacto con nuestra cultura.

Abdallah Laroui 50, miembro de la Academia marroquí y profesor de Historia en Rabat, analiza el vasto desencuentro entre el islam y la modernidad, y las varias crisis superpuestas: crisis de la ideología islámica tradicional, crisis del liberalismo árabe, crisis del socialismo árabe y crisis del arabismo. Los esfuerzos del islam para occidentalizarse han fracasado y así se ha vuelto hacia sí mismo, buscando el camino en sus teólogos y en su libro santo. Han desperdiciado así una modernización para la cual contaban con los medios abundantes materiales provenientes del petróleo. En el caso del Sha de Persia, el esfuerzo occidentalizador fue artificial, y el pueblo no conectó con él, pues sentía que el control venía de fuera aunque se hiciese a través de delegados intermedios, y por eso secundó a Jomeini. El caso del Japón, país que ha sabido modernizar su producción y convertirse en uno de los grandes países industrializados del mundo, pero conservando su "identidad" frente a Occidente, pudiera ser una fuente de esperanza.

Pero la personalidad islámica como elemento cultural y de identificación se ha forjado, además de su carácter unitario y supranacional, ya anotado, por su respuesta al "otro", al extranjero, a causa de la controvertida relación que a lo largo de la historia han vivido la civilización islámica y la occidental. Mientras Occidente descubría la ciencia y la industria modernas, los países musulmanes seguían soñando con sus pasadas glorias. Después de haber estado al frente de la civilización en la Edad Media, no se habían renovado, a pesar del desarrollo de las artes y el pensamiento en ciertas dinastías tardías, de las conquistas militares en Europa y del refinamiento de la vida cortesana.

Para el mundo árabo-islámico, hasta el siglo XIX Europa seguirá siendo "Bilad al-Ifrany" (País de los Francos, terminología medieval árabe para designar a los cruzados), anacronismo que perpetuaba la noción de extranjero unida a la de enemistad, frente a la cual la identidad islámica era el mejor refugio del "yo" frente al "otro". He aquí uno de los fundamentos de la "diabolización" de Occidente.

También en la cultura occidental existe el drama en el aceptar al otro, al diferente. Se entiende la generosidad o la solidaridad como integración del diferente en lo que nuestra prepotente racionalidad ya ha declarado como casa común o concepto universal.

En la mayoría de los países árabes el cambio a Estado-nación no ha tenido éxito. El Estado asume cierto número de responsabilidades: impuestos, instrucción, agua, electricidad, etc., pero no ha penetrado en el interior de 
las estructuras reales, de las estructuras comunitarias. Estas continúan funcionando como un cuerpo común supranacional, como un refugio, como una última defensa, como un "espíritu de familia". Sadat, al firmar la paz con Israel en 1977 abandonó el "espíritu de familia”. Y ¡nadie ha olvidado el asesinato de Sadat en 1981!

La lógica comunitaria adopta una moral que se deforma según las circunstancias y la identidad del agresor. Para superarla habría que transgredir un tabú, aceptar condenar a un hermano de raza y/o religión que pudiera no tener razón frente a un extranjero que pudiera tenerla, "mirarse en público con espíritu crítico", y separar el discurso del dictador de las convicciones populares. En otras dictaduras, por ejemplo en Iberoamérica, la gente diferencia lo que dice el tirano de lo que dicen ellos. En el mundo árabo-islámico el hecho de que la comunidad esté sumida en la desgracia hace todavía más difícil la ruptura del círculo y el poder avanzar. Parece que la comunidad afectiva entre los países árabes sólo se despierta en situaciones negativas, en las crisis, en las derrotas, en las humillaciones compartidas. El sionismo, el imperialismo y "la reacción árabe" (petromonarquías del Golfo) son los tres pilares de sus desdichas. Si uno es marxista, a estos tres pilares se los enfrentará con el nacionalismo árabe, la lucha de clases y los oprimidos; y si es islamista, con la nación islámica, la guerra santa y los desheredados; pero no hay ninguna duda sobre su identidad.

Cualquiera que sea el origen de la ideología, los nuevos regímenes autoritarios tratarán por todos los medios de "estatalizar" el islam debilitando a los ulemas y a las instituciones para eliminar toda voz islámica disidente.

La forma más corriente en muchos intelectuales musulmanes de considerar el desafío que el mundo moderno lanza a los musulmanes consiste en distinguir entre la técnica occidental, que es aceptada, y la cultura occidental, que es rechazada. Pero no es posible separar simplemente la técnica y la cultura, ya que la primera supone una orientación del espíritu en quien la pone en práctica. Toda técnica exige un arraigo en una cultura que exige al mismo tiempo idealismo y realismo en una síntesis armoniosa. Por eso el musulmán senegalés Mamadú Dia escribió: "hay que establecer sobre todo infraestructuras sociales, es decir, de las masas, motivaciones nuevas económicamente eficaces, y en concreto las dos propensiones fundamentales de toda la economía moderna, la inclinación a trabajar y la inclinación a innovar" ${ }^{51}$. No basta con querer encontrarlo todo en el Corán, ni con la adhesión a una pedagogía

51 Dia, Mamadú, Islam, société africaines et culture industrielle. Nouvelles Editions africaines, Dakar 1975, pág.153; ID, La crisis de los intectuales árabes; ID. El islam árabe y sus problemas. Península, Barcelona 1984 comprende los siguientes ensayos: "Islam y Estado"; 
memorista, ni con la solidaridad incondicional a los miembros de una familia o de un clan, ni con el exclusivo esfuerzo bélico para extender el rẻino del islam y la difusión de la lengua árabe.

En el campo irano-islámico, el filósofo Daryush Shayega 52 , afirma en términos parecidos a Laroui, que las estructuras mentales de la civilización islámica, al seguir siendo tributarias de la Tradición, han quedado rezagadas en la historia y tropiezan con dificultades a la hora de asimilar la modernidad sobre la que se fundamenta la cultura occidental. Los hombres que participan de ambas culturas - el autor es un ejemplo -, se encuentran en la "falla existente entre mundos incompatibles que se rechazan y se deforman mutuamente". Aunque son conscientes de que la historia no deja de modelar nuevas formas de producción y de relaciones sociales, el contenido de esa historia se ha forjado en su ausencia; y por la misma razón que no participaron en su génesis, no se sienten responsables de sus resultados 53 .

Por su parte, el islamólogo argelino afincado en París, Mohamed Arkoun, considera que el integrismo musulmán "utiliza una religión cortada de sus fuentes culturales y teológicas". Sin embargo, el movimiento humanista del islam, entre los siglos VII y XIII, según él, precedió al europeo. Actualmente, el discurso islamista no es popular, es populista. Hay una diferencia sustancial en el momento de la derrota entre Nasser y Sadam: el primero dimite y el segundo miente. "Es una cuestión de generación. Nasser está más cerca del concepto del honor musulmán, según el cual cuando alguien se equivoca, lo reconoce y se va. Sadam es de una generación más cínica y más moderna. El concepto de honor, como otros tantos, se ha roto en el mundo árabe" 54 .

El intelectual tunecino Moncef Mazouki 55, escribía: "Cítenme el nombre de un solo objeto de este siglo, de una sola escuela de pensamiento, de ciencia o de arte que hayamos creado nosotros". Y atribuía el estancamiento de la cultura árabe, por una parte, a la ausencia de domocracia y, por otra, "a una mala gestión de la materia gris", es decir, a una enseñanza estereotipada, que hace que subsistan entre un 60 y $90 \%$ de analfabetos, según los países.

\footnotetext{
"Islam y libertad"; "Ibn Jaldún y Maquiavelo"; "El Islam y la crisis de la Cultura"; "El Islam y Europa". ID, L'Idéologie arabe contemporaine. París 1967. 52 SHAYEgAN, Daryush, La mirada mutilada. Esquizofrenia cultural: países tradicionales frente a la modernidad. Península, Barcelona 1990.

53 Cf. NASH, Seyyed Hossein, Vida y pensamiento en el islam. Herder, Barcelona 1991.

54 INFANTE, Lola, "España debe hacer la política de su cultura", en DIARIO 16, 10-31991 (Entrevista a Mohamed Arkoun).

55 MARzouKI, Moncef, Arabes, si vou parliez.
} 
Hay muchas clases de fundamentalismo islámico. Por ejemplo, la noción de jerarquía dominada por un imán y los ayatolás ${ }^{56}$, es muy fuerte entre los shiíes iraníes, y en cambio es desconocida entre los sunníes. $Y$ es que el Corán no es un libro demasiado dogmático y sus suras permiten cualquier interpretación, según el gobernante que está ungido con el carácter de imán de los creyentes. No es lo mismo el radicalismo de los Hermanos Musulmanes adscritos a la rama más conservadora del islam, pero partidarios de las urnas, que el de los shiíes de Irán, más coránicos, más revolucionarios y más inclinados hacia la violencia y el terrorismo para conseguir una sociedad islámica, o el de musulmanes que, como tercera vía, intentan compaginar el ordenador con el Corán, sin copiar los malos hábitos de Occidente.

Mientras que para algunos, como el ateo, arabista galo y sociólogo Gilles Kepell, "la "yihad", la guerra santa, es la bomba H del Islam" 57, para otros, como Martín Descalzo ${ }^{58}$, el Corán está muy lejos de ser un libro belicoso. Si se le quita lo de algunas traducciones hechas en el Occidente medieval (ya en el siglo XIII el canónigo Marcos de Toledo tradujo el Corán completo), que eran tendenciosamente antiislámicas, y algunas frases coyunturales, el Corán es un libro de paz y la misma "yihad", es en él, las más de las veces, la lucha contra los propios instintos y, en algunos casos, la guerra defensiva contra los agresores de los fieles musulmanes: "porque han sido tratados injustamente" (C 2239), "por haber dicho: nuestro Señor es Dios" (C 2240); pero no una bandera para conquistar y someter el mundo, como entre nosotros suele pensarse. Cierto que se exhorta a luchar "por Dios con haciendas y personas" (C 941), por encima de los lazos de familia y clan (C 924); se le prometen premios a los que lo hagan (C 988; 3142 ); se amenaza con castigos y con la gehena a quienes prefieran quedarse en casa (C 981.82.85); e incluso llega a decirse: ¡"No llores nunca por ninguno de ellos cuando muera, ni te detengas ante su tumba!" (C 984).

En todo caso, parece justificar toda guerra ofensiva en contra de un país vecino que rechace el islam ${ }^{59}$.

56 El "ayatolah" es la máxima autoridad religiosa de los shiíes iraníes. Existe también el "Ayatoleslam", título honorífico con el que se reconoce a ciertos teólogos, de rango inmeditamente inferior a los ayatolás. El imán es la persona que dirige la plegaria en las mezquitas; por extensión, puede ser jefe político-religioso.

57 KEPELL, Gilles, La revancha de Dios. Cristianos, judios y musulmanes a la reconquista del mundo (Trad. Marcelo Cohen). Anaya \& Muchnik, Madrid 1991; ID. Faraón y profeta. Muchnik, Barcelona 1988.

58 Martin Descalzo, J.L., "Matar en nombre de Dios", en Blanco y Negro, 17-2-1991. De todas formas, los que mueren en la guerra santa son considerados "mártires" y testigos de la unicidad divina.

59 A nuestro juicio, creemos que por muy suave que sea la interpretación que se dé al concepto "Yihad", éste significa, al menos, un esfuerzo por extender el islam y, en ocasiones, se ha interpretado como la legitimación religiosa de una guerra. 
Mucho menos belicoso - sigue afirmando Martín Descalzo - es aún el Evangelio que se centra en "amaos los unos a los otros". El día en que Pedro le cortó la oreja a Malco, y recibió la más dura reprimenda de su maestro ("el que empuñe la espada a espada morirá"), ese día murió todo lo que pudiera significar belicismo de los cristianos. Así lo entendieron los primeros seguidores de Jesús, que hasta tenían prohibido enrolarse en los ejércitos y que practicaron aquella formulación de Tertuliano: "Cristo, al desarmar a Pedro, desarmó a todos los cristianos". Después de las cruzadas, la conciencia pacífica y pacificadora de la Iglesia no ha cesado de crecer y cada vez se atornillaron más las condiciones para que una guerra fuese justa, aunque hemos de reconocer que, a lo largo de la historia, los cristianos no siempre han puesto en práctica la fórmula de Tertuliano.

Juan Pablo II ha señalado, ante el conflicto del Golfo (1991), al mismo tiempo que se solidarizaba con las "víctimas inocentes del Estado de Israel y de la nación iraquí", que el camino de la guerra es indigno del hombre, y que son el diálogo y la paciencia terca las tareas propias de los humanos: "No se solucionan los problemas con las armas sino que se crean nuevas y mayores tensiones entre los pueblos"; "La guerra es una aventura sin retorno". (El mismo Papa ha matizado que no es pacifista, y que no quiere una paz a cualquier precio, sino la basada en la justicia y el amor) ${ }^{60}$. El 28 de julio de 1915, Benedicto XV gritó a los contendientes en la primera guerra mundial: "Sea bendito el primero que levante el ramo de olivo y tienda la mano al enemigo, ofreciéndole la paz en condiciones razonables"; y en su "Llamamiento a las partes en conflicto" del 1 de agosto de 1917, invita a los gobernantes a cesar "una matanza inútil". Pío XII en el radio mensaje del 24 de agosto de 1939, cuando apenas hacía una semana que había comenzado la II Guerra Mundial, recordó a las partes en conflicto lo irracional de una guerra: "Nada se pierde con la paz. Todo puede perderse con la guerra". Juan XXIII, en la encíclica "Pacem in Terris" (11-4-1963) indica de manera categórica: "Por esto, en nuestro tiempo, que se ufana con la energía atómica, es irracional pensar que la guerra sea medio apto para restablecer los derechos violados". Y Pablo VI, ya en la era nuclear, clamó en las ONU, "Nunca jamás la guerra".

El Concilio Vaticano II (1962-65) dedica el capítulo V de la parte II de la constitución pastoral "Gaudium et Spes" al "Fomento de la paz y la promoción de la comunidad de los pueblos". Después de hacer suyas "las con-

60 Un experto como el padre Maurice Bormans, del Pontificio Instituto de Estudios Arabes, ha declarado que teme que las antiquísimas e indefensas comunidades cristianas del Próximo Oriente, tengan que pagar las consecuencias de esta guerra. 
denaciones de la guerra mundial expresadas por los últimos Pontífices", declara (entre otras muchas cosas): "Toda acción bélica que tiende indiscriminadamente a la destrucción de ciudades enteras o de extensas regiones junto con sus habitantes, es un crimen contra Dios y la humanidad que hay que condenar con firmeza y sin vacilaciones. El horror y la maldad de la guerra se acrecienta inmensamente con el incremento de las armas científicas" (n. 80). “(...) debemos procurar con todas nuestras fuerzas preparar una época en que, por acuerdo de las naciones, pueda ser absolutamente prohibida cualquier guerra" (n. 82).

La Conferencia Episcopal Española se ha remitido al documento "Constructores de la paz" (1986), en el que se afirmaba que "resulta un absurdo sostener que la guerra es un medio apto para resarcir el derecho violado". El secretario general de la Conferencia Episcopal, Mons. Agustín García Gasco declaró taxativamente: "La guerra es incompatible con el Evangelio". En todo caso, los obispos españoles han dicho que ésta no ha sido una guerra de religiones. En el lado occidental, a excepción de algunas declaraciones del Presidente norteamericano Bush, no se ha recurrido a la legitimación de unas nuevas cruzadas, lo cual no hubiera estado en consonancia con una sociedad laica y secularizada.

De forma muy diferente piensa Karlheinz Deschner sobre las relaciones de la religión judeo-cristiana con la guerra. Para él, en la religión mosaica, Yahveh es el Dios de los Ejércitos, patronazgo poco tranquilizador. Y en el cristianismo, aunque los teólogos prefieren hablar de guerra justa antes que de guerra santa, se han cometido atrocidades sin número en nombre o a pesar del "amaos los unos a los otros" 61.

De todas formas, la guerra santa no es una exclusiva islámica, ni una exclusiva de las religiones. Conceptos tan seculares, "inocentes" y vocacionalmente revolucionarios como humanidad, democracia, nacionalismo, anticolonialismo, pacifismo radical, indigenismo (teoría del "buen salvaje"), etc., han servido para legitimar la colectivización de la violencia para imponer el "bien" 62. Hoy, incluso desde esferas seculares, se reconoce que sin "el perfeccionamiento pacíficamente íntimo de cada cual y el esfuerzo por establecer un marco jurídico en el que pueda prosperar una convivencia desarmada y universal" ${ }^{63}$, no es posible una auténtica paz basada en la justicia.

61 Cfr. Deschner, Karlheinz, Historia criminal del cristianismo. 1990

62 En el prólogo a la obra de Franz FAnON, Los condenados de la tierra, Jean-Paul Sar. tre escribió: "Tras el acto de disparar contra un colonialista queda un hombre muerto y u1 hombre libre".

63 Savater, Fernando, “Yihad”, en El País Semanal, 10-2-1991. 
Ante tantas opiniones y sentimientos encontrados, parecería que los únicos que pueden tender un puente entre el cristianismo y el islam, entre la paz y la violencia, son los místicos y los disidentes, que viven "a la intemperie de Dios y en permanente búsqueda". Pero éstos parece no contar demasiado en los planes de los poderosos de la tierra.

Si bien, casi todas las religiones son acusadas, de alguna forma, de antifeminismo, la idea de la supremacía del hombre con relación a la mujer es muy profunda en la sociedad patriarcal y profundamente machista del mundo islámico ${ }^{64}$. Tanto el Corán como el conjunto de la sociedad musulmana ofrece la impresión de que la vida se encuentra fuertemente sexualizada, de manera que todo encuentro personal de un varón y una mujer tiende a interpretarse como "peligroso". La mujer no debe disentir de la forma de pensar del marido. En el artículo 115 de la Mudawana (Código del Estatuto Personal de Marruecos) se dice: "Toda persona subviene a sus necesidades por sus propios recursos, excepto la esposa, cuya manutención incumbe al esposo" 65. El voto de la mujer, por otra parte, no parece entrar dentro de la cultura islámica que considera, además, "poco respetable que las mujeres trabajen, y menos que salgan a Europa". Y las transformaciones políticas, cuando las hay, no siempre consiguen modificar los hábitos consuetudinarios de la sociedad.

En la literatura occidental ha existido una morbosa curiosidad por el "harem" y el fenómeno de la convivencia femenina en reclusión y al servicio de la voluptuosidad del gran señor. Los países de cultura árabe-islámica aparecen para el amante erotómano occidental como un edén de poligamia complaciente, desposeída del contexto histórico y antropológico propios, para reducirla a la imagen de una complacencia voluptuosa que la moral sexual cristiana se guarda bien de legitimar en el seno de las sociedades que gobierna.

64 La supremacía del varón sobre la mujer está bien determinada en el islam: "Los hombres tienen autoridad sobre las mujeres en virtud de la preferencia que Dios ha dado a unos más que a otros y de los bienes que gastan.(...) ¡Amonestad aquéllas de quienes temáis que se rebelẹn, dejadlas solas en el lecho, pegadles.." (C 434). "Las mujeres carecen de autonomía social propiamente dicha: varones y mujeres no conviven en lo externo; no se encuentran en lugar abierto, no dialogan en público. Ellas habitan dentro de la casa, construyendo de esa forma un mundo femenino, separado del mundo exterior de los varones, a quienes encuentran sólo en la intimidad de la casa familiar o el lecho". PrKazA, Xabier, Las mujeres en las grandes religiones. Desclee de Brouwer, Bilbao 1991, pág. 139.

65 Cfr. Mernissi, Fátima, Marruecos a través de sus mujeres. Ediciones del Oriente y del Mediterráneo, Madrid 1991. Esta socióloga ya había planteado reivindicaciones "feministas" en su tesis de doctorado, Sexe, Ideologíe, Islam. Edit. Tierce, París 1983. 
Sólo cuando la emancipación real de la mujer occidental cobró vigor, a finales de siglo XIX, con el feminismo, se inició una transformación perceptiva de la condición femenina en los países árabes ${ }^{66}$. Desde hace algunos años, también la mujer árabe emancipada se ha convertido ella misma en portavoz del problema.

Si bien las mujeres de Mahoma, Khadija, su primera cónyuge era próspera mujer de negocios y Aisha, la favorita que era juez, por ejemplo, eran activas, y la religión que fundó el Profeta prohibió el infanticidio femenino, estableció la educación de las mujeres como un deber y reconoció su derecho a la propiedad y a la herencia, la tradicional condición de la inferioridad de la mujer se agudiza en los países donde resurge el fundamentalismo. Como afirma Leila Aslaowi, juez argelina, "este mundo de infelices cubiertas de velos no es el islam”. Claro que, si para los occidentales el velo es un símbolo de opresión, esa podría no ser la cuestión, pues como escribe la parlamentaria egipcia de religión cristiana, Leila Takha, "mientras las mujeres escondan la cabeza, pero no el cerebro, es sólo una cuestión de elección individual". El problema es que parece que no siempre se trata de una elección individual, sino de una imposición; y aun en el caso en que pudiera tratarse de una "elección individual", podría deberse a una presión alienadora de la tradición o del ambiente.

En el campo, el pudor de las mujeres se manifiesta sólo viviendo separadas de los hombres, y en las ciudades, aunque desde principios del siglo $\mathrm{XX}$ las prácticas son diferentes según los países, las musulmanas deben velarse desde los primeros síntomas de la pubertad, excepto en el círculo familiar con los hombres con los que les está prohibido el matrimonio en virtud del parentesco y con los parientes de sus hermanas, sobrinas, etc. Especialmente dura es la secta de los Wahhabiyah, un movimiento fundado en el siglo XVIII, que cuenta entre sus seguidores a la familia real saudí. A las mujeres Wahhabi, además de vivir ocultas por el velo, se les prohíbe conducir y sólo pueden viajar si van acompañadas por el esposo o por un pariente varón. En todo caso, incluso después de la supresión del velo, la presencia de las mujeres en la sociedad masculina sigue siendo muy discreta.

En el Corán se afirma también que la mujer es "un ser que crece entre perifollos, incapaz de discutir claramente" (C 4318). El matrimonio puede realizarse entre menores, mediante la firma de un contrato entre las familias, que intervienen en la elección de los esposos, y para cuya validez basta con

66 Cfr. Ruiz de Almodovar, Caridad, Historia del movimiento feminista egipcio. Feminae, Universidad de Granada 1989. 
el silencio de la mujer, si bien el Corán establece que "no es lícito recibir en herencia a mujeres contra su voluntad..." (C 419). En las zonas rurales de Pakistán, Malasia y Tailandia los padres siguen concertando el matrimonio de las hijas antes de la pubertad. Desde el principio de los años ochenta, en Filipinas, Singapur, Hong-Kong y Japón, predomina la libre elección del cónyuge.

Aunque la ley afirme que "el repudio es la más odiosa de las cosas lícitas", el hombre es libre de despedir a su mujer y no tiene que dar cuenta a nadie de esa decisión. El código familiar adoptado por Argelia en 1984 da al hombre el derecho de divorciarse de su mujer por cualquier razón y expulsarla del hogar. En Egipto, la Corte Suprema revocó en 1985 una ley de 1979 que otorgaba a la mujer el derecho de divorciarse de los maridos que tomaban una segunda esposa.

La custodia de los niños se le confía a la madre hasta los siete años y después vuelven automáticamente al padre. Pero el apóstata musulmán pierde sus derechos a la herencia y a la vez queda automáticamente divorciado de su esposa musulmana.

Durante la vida del profeta, los árabes admitían el "mut'a", el matrimonio temporal de "disfrute". Aunque los sunníes lo prohíben en la actualidad, los shiíes lo consideran lícito, y en las obras del ayatolá Jomeini, por los años 1970-1980, se encuentran alusiones a ese matrimonio.

$\mathrm{El}$ islam permite la poligamia (más exactamente la poliginia) con dos condiciones: que el número de esposas no pase de cuatro y que el marido las trate con equidad, sin favorecer a una a costa de las otras. Además de esas cuatro mujeres de primer rango, el Corán admite otras, sin limitación de número, de las esclavas concubinas. La mujer esclava que haya dado un hijo al amo forma una categoría aparte, no puede ser vendida y tiene que ser liberada al morir su amo (C $\left.4^{2-4}\right)$. Sin embargo, el hijo de una pareja de esclavos que pertenecen a un mismo amo son propiedad legal de éste.

La práctica de la poligamia ha descendido en las regiones influenciadas por la cultura árabe-musulmana de norte de Africa, como Argelia, Marruecos y Túnez. De hecho, este último país es el único que la ha prohibido legalmente. Pero sigue predominando en Camerún, Costa de Marfil y Senegal, donde el porcentaje de mujeres que comparten el esposo con otras esposas legítimas supera el $40 \%$. En Asia esta práctica es mucho menor, siendo Kuwait y Barain los países con el porcentaje más alto, 11\% y $5 \%$ respectivamente. En Siria, Líbano, Jordania, Yemen y los Emiratos Arabes Unidos no llega al 5\%, y entre los habitantes de la India el matrimonio tiende hacia la monogamia. Debido a la poliginia, al menos en parte, todos los países musulmanes tienen generalmente elevadas tasas de natalidad. 
El musulmán puede casarse con una no musulmana de "entre las gentes de la Escritura", es decir, cristianas o judías, pero no de otras religiones, a no ser que ella se haga musulmana. La cristiana o judía que se casa con un musulmán puede guardar su fe y practicar su religiőn, pero sus hijos tendrán que ser musulmanes. En caso de divorcio o fallecimiento del marido, los niños les serán retirados a la madre si no se hace musulmana, y no recibirá la parte de la herencia que se prevé normalmente para una viuda, si no se convierte. Este doble motivo incita a muchas mujeres a renegar en estos casos de su fe judía o cristiana. En todo caso, en la distribución de la herencia, en el mismo grado de parentesco, la mujer recibe una parte equivalente a la mitad de la de los hombres. No obstante, la esposa puede gastar su fortuna propia sin tener que autorizárselo el marido.

Las musulmanas sólo pueden casarse con un musulmán. El cristiano o el judío que quiera casarse con ella tiene que hacerse musulmán. Por esto, los matrimonios mixtos han sido ocasión muy frecuente de islamización.

El adulterio está castigado en la ley islámica con la muerte de los culpables, siempre que el acto esté bien confirmado o por confesión o por cuatro testigos varones (C 244-26).

En cuanto al aborto, el Corán (1731) dice: "No matéis a vuestros hijos por temor a empobreceros". La ley lo prohíbe cuando está animado el feto. Los ulemas piensan que el feto no es un ser humano hasta después del cuarto mes. Por eso se permite generalmente el aborto durante los primeros noventa días del embarazo, y se prohíbe por prudencia después. En Irak sólo está permitido para salvar la vida de la madre. La planificación familiar moderna (píldoras, esterilización, DIU, condones, etc.) es una cuestión de formación personal porque en la religión islámica no se hace ninguna referencia específica a este tema.

La idea de permanecer voluntariamente en el celibato es extraña al pensamiento musulmán, que considera que el hombre y la mujer no alcanzan la plenitud de su personalidad más que con la paternidad o la maternidad. Una tradición que se remonta a Mahoma enseña que "el matrimonio es la mitad de la religión". No obstante, la continencia es obligatoria antes del matrimonio y ven con respeto la virginidad de María, el nacimiento virginal de Jesús y el hecho de que ni Juan Bautista ni Jesús tomaran esposa.

El Corán, desde la perspectiva de "revelación literalista de Dios", que ha fijado ya para siempre las formas de existencia humanas y ha absolutizado una norma relativa de relación social, declarándola sagrada y normativa, se encuentra más limitado que otras religiones en la búsqueda de soluciones a la liberación o realización de la mujer en cuanto tal. La mujer se encontraría sometida para siempre a los varones. 
Por todo lo expuesto, si es evidente que Mahoma mejoró la condición de las mujeres de su sociedad y de su tiempo, no obstante, algunos piensan que "al menos respecto a la mujer, el Islam es regresivo en relación al cristianismo: retrocede hacia posturas que podemos llamar precristianas (y en algún sentido hasta prejudías)" 67. El mismo Cardenal de París, Jean Marie Lustiger, acaba de afirmar en un seminario organizado por la Universidad Complutense en El Escorial que, "si el problema de la mujer se debate en Occidente, es porque el cristianismo lo ha planteado, ya que no sucede lo mismo en las civilizaciones, por ejemplo, islámicas". No deja de llamar la atención que incluso en estos momentos (noviembre de 1991) en Argelia se esté discutiendo el artículo 54 de la ley electoral, que permite al marido votar por la esposa sin otro requisito que el de presentar el libro de familia ante las urnas, y que el Código de Familia de 1984 haya restaurado el derecho a la poligamia y la tutela permanente del marido sobre las acciones y decisiones de su esposa.

Son numerosos los puntos de coincidencia doctrinales entre el cristianismo y el islam, como recoge el Conc. Vaticano II (como lo hace con otras religiones, como el judaísmo) ${ }^{68}$, pero también son notorias sus diferencias, como hemos anotado. Incluso en prácticas similares, como el descanso semanal, el sábado judío no puede compararse al viernes musulmán o al domingo cristiano. En el primero predomina la prohibición del trabajo, la conmemoración de la liberación de Israel de Egipto y la creación del mundo. Para el musulmán hay obligaciones más graves que el descanso del viernes, como la oración, la limosna, el ayuno y la peregrinación a la Meca. Y Jesús de Nazaret se proclamó "Señor del sábado", practicó curaciones ese día y defendió que el espíritu estaba por encima de la ley.

Pero quizá, más importantes son aún las desavenencias y enemistades que han surgido en el decurso de la historia entre dos de las religiones de los "grandes mediadores". Por eso el mismo Concilio "exhorta a todos a que, olvidando el pasado, procuren sinceramente una mutua comprensión, defiendan y promuevan unidos la justicia social, los bienes morales, la paz y libertad para todos los hombres" 69.

67 PIKazA, Xabier, op. cit., pág. 137. Para una visión completa del tema de la mujer en el islam cfr. GARDET, L., L'Islam. Religion et communauté. DDB, París 1970; SCHACHAT, J., Esquisse d'une histoire du droit musulman. Besson, París 1953; PAREJA F. M., La religiosidad musulmana. BAC 374, Madrid 1975; NASR, S. H., Vida y pensamiento en el Islam. Herder, Barcelona 1985.

68 Cfr. sobre todo la constitución "Lumen Gentium" y la declaración "Nostra aetate". Documentos del Vaticano II. BAC 42, Madrid 1990, págs. 52 y 615.

69 Declaración "Nostra aetate”, op. cit., pág. 615. 
El mismo Papa Juan Pablo II ha mantenido numerosos encuentros con grupos musulmanes a lo largo de sus viajes, en especial al Africa, en donde afirmó en septiembre de 1990: "La tradición africana de convivencia entre ambas comunidades es buena; los musulmanes africanos son tolerantes y respetuosos con las comunidades católicas" 70 . Y sólo en un clima de comprensión puede entenderse la carta que en 1991, por primera vez en la historia, un Papa ha enviado al mundo musulmán con ocasión del fin del ayuno de ramadán y después de la guerra del Golfo. En otras circunstancias este gesto hụbiera sido considerado, al menos, como una intromisión intolerable.

Aparte del hecho estrictamente religioso y sus condicionamientos, el problema es que el mundo árabe-islámico tiene estrategias distintas para conseguir el poder, pero no posee ningún proyecto para construir una sociedad moderna dentro del Islam. El proyecto político basado en el populismo no ha alumbrado concreciones válidas. La dirigente argelina Wassyla Tamzalli opina que "el integrismo es el sida de las sociedades islámicas. Y nadie conoce su antídoto".

Algunos líderes árabes, como Gaddafi, reconocen el Corán pero no la "saría", la ley islámica práctica, que los siglos han sacado del Libro Santo, a la que considera "interesante", pero no fundamental. La interpretación que hacen los wahabíes de Arabia Saudí de la sharía es totalmente distinta de la que hacen los shiíes. Estos tratan de radicalizar un mensaje en el que la sociedad civil y el sistema político aparecen subordinados al religioso, como meras expresiones imperfectas de una organización social teocrática. El líder de la OLP, Yásser Arafat sueña con un estado secular, en oposición al movimiento integrista de los Hamas, que cuenta con el apoyo del $25 \%$ de los palestinos.

Parece ser que el sentimiento religioso es el único resorte que les queda a los líderes árabes para aglutinar al pueblo, y por eso invocan a la "Yihad" cuando intentan establecer un orden islámico en el mundo. Al lema de Marx, "Proletarios del mundo, uníos", corresponde de hecho otro lema, quizás no tan formulado, pero que inspira de hecho a muchos líderes: "Musulmanes de todos los países, uníos". No compartimos la opinión del arabista Pedro Martínez Montávez cuando afirma que "el principal soporte del Movimiento Neoislámico Panarabista era la lengua y la convicción de pertenecer o ser depositarios de un patrimonio histórico y civilizador común. (Y que) el soporte islámico como religión era secundario". Esta interpretación pudiera

70 Citado por Antonio Pelayo, Juan Pablo II en el calvario africano, en Ecclesia 22-91990, pág.15. 
ser propia de una visión secularizada de la vida, característica de una mentalidad occidental. Como afirma Bernard Lewis: "el islam proporciona el sistema de símbolos más efectivo para la movilización política (...) y sigue siendo la base de autoridad más aceptable, de hecho, en tiempos de crisis, la única aceptable". No parece caber duda de que el islam es el "alma de la arabidad", el que "ha salvado la identidad de los países árabes y musulmanes (...) en el período de la colonización europea", como afirma el arabista argelino Jacques Berque.

La frontera entre las sociedades ricas y pobres para explicar el surgimiento de núcleos fundamentalistas no está clara, ya que el fenómeno ha aparecido indiscriminadamente tanto en los países islámicos ricos, como Libia, Argelia o Arabia Saudí, como en los pobres, como Egipto o Marruecos.

Cada vez que se producen elecciones se registran avances en los partidos integristas: Egipto en 1987, Túnez y Jordania en 1989, Argelia en 1990. En Túnez, los dirigentes del ilegal partido An-Nahda tomaron en marzo de 1991 la sorprendente y atípica decisión política de "autocongelarse" "para evitar una guerra civil". Y, lo que afecta más directamente a Occidente, se detecta una creciente inquietud en las comunidades musulmanas radicadas en Europa, principalmente en Francia, donde el islam se ha convertido en la segunda religión de la nación, y en el Reino Unido. El uso del "chador", por ejemplo, comenta Alain Finkielkraut, "no es sólo un signo religioso, y no se permiten los signos religiosos en la escuela pública francesa, sino un signo de la relegación de la mujer en la fe islámica". El periodista francés Jean Francois REVEL constata, al mismo tiempo, la falta de lógica de los "beurs" - jóvenes árabes nacidos ya en Francia - cuando exigen, con razón, beneficiarse de todas la garantías del Estado de derecho y de todas las ventajas de la sociedad desarrollada, pero siguen manteniendo comportamientos irracionales (lo árabe por ser árabe). Esto, sin hacer mención de la escasa o nula libertad que se concede en los países de tradición musulmana (a excepción de algunos africanos) para practicar otras religiones, a pesar de que en el Corán se afirme "no cabe coacción en religión" $\left(2^{256}\right)$, lo que pudiera apuntar al principio de libertad religiosa, difícil de compaginar, por otra parte, con la doctrina tradicional que niega al musulmán la libertad para cambiar de religión. 


\section{EL ISLAM Y OCCIDENTE}

El historiador norteamericano Bernard Lewis 71 estudia las relaciones entre el Islam y Occidente, y nos recuerda que, el islam tras haber sido una fuerza culturalmente dinámica durante cinco siglos, entre sus orígenes y nuestro siglo XII, se hunde durante siete siglos en un aislamiento autárquico y culturalmente trágico, que le hace vivir su identidad cultural como un rechazo contra lo que considera la barbarie occidental. Durante los siglos XII al XIX, Occidente vive y protagoniza varias revoluciones culturales que transforman las relaciones del hombre con la técnica, la cultura y la producción industrial. A un creyente musulmán, las ambiciones de la civilización occidental, con su dimensión prometeica, le parecen desmesuradas e inaceptables.

En 1948, con la primera guerra árabe-israelí se produjo un profundo golpe psicológico en la conciencia de los árabes. Bernard lo describe así: "sorprendidos y mortificados, los árabes no conseguían entender cómo los hombres que habían considerado siempre como débiles, cobardes y despreciables - hombres que Dios había castigado, rebajándolos y humillándolos habían podido inflingirles una derrota tan dolorosa. Ahora eran ellos - y para algunos el conjunto de la nación musulmana - quienes conocían la humillación" 72. Y Las esperanzas de unidad del mundo árabe se hundieron cuando Nasser perdió la guerra de 1967. Por eso, quizá la única forma de superar esos sentimientos de humillación sería la aplicación de las resoluciones 242 y 338 de las Naciones Unidas sobre la retirada israelí de los territorios ocupados en 1967, cosa, por lo que se está viendo, nada fácil.

Además, durante siete siglos Occidente aprendió a conocer el islam. En 1539 se funda en París una primara cátedra de árabe. Los arabistas británicos crean otra cátedra en 1633. Durante los primeros años del siglo XVIII, Occidente tiene ya unas setenta gramáticas de árabe. Por el contrario, el primer diccionario de árabe a una lengua europea no se publicará hasta $18288^{73}$.

71 LEwIs, Bernard, The Muslim Discovery of Europe. Nueva York 1982.

72 ID., Semitismo y antisemitismo. Citado por BASSETs, Lluís, La herida, en EL PAIS, 21-2-1991.

73 En el caso español las relaciones hispano-árabes que han sido cubiertas bibliográficamente con alguna densidad por autores connacionales, son las relacionadas con Marruecos, con el que nuestra vecindad ha sido "asunto importante, complicado e inevitable". Véase, por ejemplo: Allende SAlAzAR, J.M. La diplomacia española y Marruecos: 1907-09. Agencia Española de Cooperación Internacional, Madrid 1990. Del Pino, Domingo, Marruecos entre la tradición y el modernismo. Biblioteca de Ciencias Políticas de la Univ. de Granada,1990. UNED (coedición), Estudio sobre el mundo árabe e islámico contemporáneo. Agencia Española de Cooperación Internacional, anejo al volumen XI, 1990. MARQUEZ Villanueva, El problema morisco. Libertarias. Madrid 1991. 
A lo largo de los últimos 15 años dos movimientos reislamizadores se han disputado la adhesión de los musulmanes. El movimiento de reislamización "desde arriba" trataba de cumplir la misión que no desempeñaban los ulemas debilitados o funcionariados: expresándose. "en nombre de Dios" e interpretando a su manera los textos del Corán denunciaban, al mismo tiempo, el poder "impío" y la injusticia social y clamaban por la "guerra santa". El movimiento de reislamización "desde abajo", carecía de ambición revolucionaria explícita y trataban de paliar las carencias del Estado en todos los campos (educación, sanidad, desempleo...), de reorganizar en torno a la red de las mezquitas, una especie de contrasociedad que obedecía estrictamente a las disposiciones del texto sagrado. Este movimiento, a diferencia del anterior, gozaba de un arraigo popular real y también de la mansedumbre de los poderes establecidos, que veían en él un derivativo conservador de las formas políticas radicales, cuya lealtad se facturaría en petrodólares, y una forma de propagar el islam por todo el planeta.

La influencia de Occidente - afirma Daryush -, suscita actualmente en el mundo islámico, al menos, una triple reacción: regresión hacia una mitología de los orígenes, que se supone resolverá milagrosamente las miserias y desigualdades sociales que padecen las sociedades que lo componen; huida hacia adelante "en pos de aventuras progresivamente más peligrosas"; y una negativa categórica a responder a los desafíos de los nuevos tiempos. Todas estas "escapatorias" reflejan un profundo malestar proveniente de la falta de asimilación de la modernidad, fenómeno histórico que ha inflingido transformaciones traumatizantes a las tradiciones, a las formas de vida y a las formas de pensar de las culturas orientales.

Al contacto con la potencia material de Occidente - sigue afirmando este autor -, la primera reacción del islamismo fue entusiasta y descubrió, sor-

Para una visión breve de la España islámica, puede verse MONTGOMERY WART, W., Historia de la España islámica. Alianza editorial, Madrid 1982. También existen algunas obras, fundamentalmente de divulgación, sobre el islam en general, por ejemplo: LARROQUE, Enrique, El poder del islam. Biblioteca Universitaria, Madrid 1991; MuÑoz MolinA, Antonio, Córdoba de los omeyas. Planeta, Barcelona 1991.

Con una gran participación internacional y patrocinada por el Metropolitan Museum de Nueva York, que tiene la mayor colección del mundo de arte islámico, y el Banco Bilbao Vizcảya, se inaugurará en la Alhambra de Granada, en marzo de 1992, la exposición "AlAndalus: las artes islámicas de España".

Un coloquio sobre "La contribución de la civilización islámica a la cultura europea" se desarrolló del 28 al 30 de mayo de 1991 en París, organizado por la Comisión de Cultura y Educación de la Asamblea Parlamentaria del Consejo de Europa, en colaboración con el Instituto Occidental de Cultura Islámica, con sede en Madrid. Otro coloquio internacional sobre el "Diálogo filosófico religioso entre cristianismo, judaísmo e islamismo durante la Edad Media en la Península Ibérica" tuvo lugar en El Escorial entre el 23 y el 26 de junio de 1991. 
prendido, su propio retraso y el enorme abismo que lo separaba de Europa. Pero, cuando más adelante, 'se cerró a su influencia, ese mismo mundo adoptó un "lenguaje histérico de una repulsa obsesiva". Occidente nunca fue considerado como un "paradigma nuevo que rompía con el pasado, sino como una conspiración de fuerzas ocultas que depravaba sus costumbres y, a la larga, le reducía a la esclavitud política y cultural".

El mundo musulmán sufre desde hace décadas el impacto de dos tentaciones contradictorias: la de la autoafirmación integrista y la de la incorporación a un mundo moderno que anhelan y, al mismo tiempo, temen. Durante un tiempo, el juego de estos dos vectores de fuerza se proyectó en una "tercera vía": la del nasserismo o sus equivalentes, en la cual se combinaba una apelación a principios de justicia social con un panarabismo reinvindicativo y de índole "terapéutico". Pero el experimento fracasó, ya que los derechos y libertades individuales de Occidente no son trasplantables a las culturas orientales sin marginar aquellos valores tradicionales que ocupan totalmente su espacio público. Como señalaba, ya en los años sesenta, el filósofo francés Jean Fraçois Lyotard, "sería absurdo aplicar al islam categorías típicamente occidentales como socialismo, racionalismo, irracionalismo, guerra de liberación". Y desde el campo gnoseológico, "la lengua árabe, en la que cada palabra conduce a Dios; fue concebida para encubrir la realidad, no para captarla" 74 .

Para otros, como Marwan Tahbub, el caldo de cultivo del integrismo es la presencia de un Occidente hostil (EE.UU.), o en el mejor de los casos indiferente (CE), de Israel como avanzadilla de este Occidente militar y en expansión. Fundamentalmente es el producto de una crisis estructural de identidad, de falta de perspectivas para el futuro y de desconfianza en las relaciones euro-árabes.

El tunecino Hichem Djaït, en una de sus principales obras ${ }^{75}$, afirma que el "nacimiento de Europa se realizó, y no podía ser de otra forma, por mediación del islam: primero, como repliegue defensivo; después como expansión conquistadora; (...) y fue el islam el que actuó de "escudo protector" frente a las grandes marejadas del Este, el que absorbió en 1258 como un veneno mortal la plaga mongólica, el que detuvo en una segunda fase la oleada timúrida (de Tamerlán). Si Europa, cabeza de Asia, sobrevivió y se consolidó fue gracias a la circunstancia de un milenio de paz".

74 Shayegan Daryush, op. cit., pág.12.

75 DJAIr, Hichem, Europa y el Islam. Libertarias, Madrid 1990; ID., La grade discorde. Religion et politique dans l'Islam des origines. Gallimard, París 1990. 
Para el escritor libanés Amín Maluf 76 "Occidente nunca ha apoyado la democracia en el mundo árabe, sino que ha perjudicado a las élites árabes que querían esa evolución, y cerrar los ojos ante esa actitud acaba por pagarse". De todas formas, cree que la "evolución en el mundo árabe es nefasta" y que el problema arrastrado en su historia contemporánea es el de lograr un salto hacia la modernidad, "que no tiene que ser en modo alguno una imitación del modelo de civilización occidental". Pero en los países islámicos se sigue asimilando modernidad y Occidente, y "la situación se pudre". Occidente tiene que apoyar sin excepciones y por todos los medios la evolución democrática. "Si mañana se produce una represión del movimiento islamista en algún país árabe, Europa no debe aplaudirla, sino exigir el respeto a los principios democráticos. No hay países inmaduros para la democracia: aducir esto es racismo". Sin duda, el señor Maluf nos plantea el problema no claramente resulto en la misma sociedad occidental, de si la democracia puede o debe permitir los movimientos totalitarios dentro de su seno. En teoría parece claro, pero un asunto muy diferente es la práctica. Cuando menos nos parece exótica la hipótesis que plantea el sociólogo Enrique Gil Calvo en una entrevista. Según él, los árabes se resisten a democratizarse "porque su vida colectiva resulta más atractiva que lo que les ofrece el Estado a la occidental", ya que el "Estado, o es una fiesta, o no es. En cambio, si la URSS hace agua actualmente, es porque sus ciudadanos no ven una posibilidad de Estado, de "polis", como fiesta".

En 1930, un millón trecientos mil europeos aproximadamente residían en el Magreb, y 3.800.000 hectáreas de tierra magrebí se encontraban en manos europeas. Hoy día, apenas quedan europeos ni propiedades europeas en el Magreb y, a través de la emigración, el islam entra una vez más en la historia de las poblaciones europeas, lo que "ha hecho que la mirada del Occidente cristiano hacia el islam se traslade del exterior al interior de sus fronteras" 77 .

Paul Balta 78 , Director del Centro e Estudios Contemporáneos de Oriente de la Universidad de la Sorbona, nos ofrece algunos datos estadísticos de 1986 sobre la relación numérica entre católicos y musulmanes en algunos de las principales países no musulmanes:

76 MALUf, Amin, Las cruzadas vistas por los árabes. Alianza.

77 Dasseto, F., L' Islam transplanté. Citado en Martin Muñoz, Gema, "La política del islam", en El PAIS, 21-2-1991.

78 BALTA, P., L'Islam dans le monde. La découvert - Le monde - París 1986, págs. 344351. 


\begin{tabular}{lrrrr} 
& Católicos \% & Musulmanes \% \\
\hline Francia & 47.440 .000 & 84,9 & 2.798 .000 & 5 \\
Alemania & 27.930 .000 & 45,6 & 2.103 .000 & 2,7 \\
Reino Unido & 5.074 .000 & 9,3 & 767.000 & 1,4 \\
URSS & 13.000 .000 & 4,7 & 49.981 .000 & 18 \\
Estados Unidos & 54.000 .000 & 22,2 & 3.449 .000 & 1,4
\end{tabular}

(Nota.- Los católicos en países musulmanes apenas superan los 150.000)

En la CEE viven unos seis millones y medio de musulmanes a los que se les pide su inserción en contextos sociales regidos por el laicismo. Pero, ¿puede un Estado laico integrar el Islam sin desislamizarlo? Por otra parte, la presencia de estos núcleos musulmanes ya ha originado las primeras y alarmantes tensiones de signo xenófobo y racista, que a su vez alienta el radicalismo entre los inmigrantes.

En el año 2020, calculan los institutos de investigación italianos, la población del Magreb, unida a la de Turquía, rebasará los 300 millones de personas, más habitantes que en la CE. Su baja renta "per capita" les obligará a buscar dinero donde está, en el Norte ${ }^{79}$.

Los musulmanes que vienen a Europa tienen una cultura que hace casi imposible su asimilación, mientras que para el país de acogida, como afirma el orientalista francés Bruno Etienne, el mejor emigrado sigue siendo el que desaparece, bien porque regresa a su tierra o porque se hace francés, republicano y laico. Para el filósofo francés, de origen judío, Alain Finkielkraut, “estamos enfrentados al mundo árabe musulmán, al islam. Este es el único grupo humano que plantea dificultades, porque acarrea consigo un tipo de sociedad, una serie de costumbres que son contrarias al ordenamiento jurídico francés y que por ello debe ser prohibido". Si la integración no se hace respetando ciertos principios "se va al tipo de integración a la americana, acumulación de guetos, y de eso es de lo que Europa tiene que defenderse. La idea europea de la cultura, debe afirmarse sin complejos". Por otra parte, sigue afirmando Alain, "jamás se ha visto a un intelectual árabe movilizarse por una causa no árabe" 80 .

Sin negar la parte de verdad que puedan esconderse bajo esas aseveraciones, consideramos con el director del Instituto del Mundo Arabe, de

79 No podemos olvidar que en el sur de la URSS viven 50 millones de musulmanes, con un gran potencial de inestabilidad en el frente político-económico ruso.

80 BASTENIER, M.A., El peligro es el islam, en EL PAIS 21-11-1990 (Entrevista a Alain Finkielkraut). 
París, Edgar Pisani que, bien pudiera ser que "el laicismo haya pasado de expresar un proyecto de vida regido por la tolerancia a expresar una militancia sectaria y dogmática".

El mismo grupo de Trevi sigue utilizando conceptos como "comunidades de riesgo", que graban en el subconsciente colectivo europeo la hostilidad hacia miembros de la comunidad por su origen racial, confesional o lingüístico. Para la mayoría de los occidentales, el islam no ha dado ni libertad, ni bienestar, ni progreso a los pueblos.

El fundamentalismo islámico en su versión shií esta financiado por los ayatolás persas, pero el islam sunní esta financiado y alentado por naciones ligadas a Occidente, por Arabia Saudí (el rey Fahd se autotitula "guardián de los santos lugares" y durante la última peregrinación a la Meca regaló a los albaneses 250.000 ejemplares del Corán), ayudada por Kuwait, Pakistán y Marruecos (Hassan II se autotitula "príncipe de los creyentes"), sobre todo a través de la OPEP, del Banco Islámico de Desarrollo (BID), y de la sociedad de inversiones Dar al Maal al Islami (DMI). El gobierno de Arabia Saudí es el auténtico foco expandidor del fundamentalismo islámico por todo el mundo. El camino habitual es financiar servicios y obras, y a cambio instalar una mezquita (como la mezquita de la M-30 de Madrid) y una escuela coránica. No es ningún secreto que los regímenes conservadores musulmanes han utilizado durante muchos años la religión como medio de contención ante la agitación social y la expansión de las ideas igualitarias.

El caso del escritor británico Salman Rushdie, nacido en una familia musulmana no practicante de Bombay, y condenado a muerte en febrero de 1989 por un decreto religioso ("fatwas") del fallecido ayatolá Ruholá Jomeini, guía espiritual de la Revolución islámica de Irán, a causa de la publicación del libro titulado "Versos satánicos", considerado como sacrílego, es visto en Occidente como un caso claro de intolerancia religiosa. Según confesión del mismo Salman ${ }^{81}$, él sólo "trataba de dar una visión laica y humanista sobre el nacimiento de una gran religión universal". De nada ha servido la muerte de Jomeini, ni la presión de los medios de comunicación en defensa de la libertad de expresión, ni la profesión de fe islámica que Rushdie hizo a finales de 1990, ni su renuncia al derecho de publicar su obra en una edición en rústica. La conferencia religiosa islámica, reunida en Teherán a finales de febrero de 1991, le sigue considerando un "apóstata", para el que el perdón no es posible, a pesar de su arrepentimiento e, incluso, se ha duplicado la recompensa por su ejecución, ya que, según el ayatolá Yusef

81 Rushdie, Salman, Elegir entre la luz y las tinieblas, en Diario 16, 5-2-1989. 
Sanei: el decreto del imán "se promulgó para hacer frente a un complot cultural fomentado contra los fundamentos mismos del islam y contra los desheredados". Parece que los ayatolás se han olvidado de : "Quedan exceptuados (de la muerte sin piedad) quienes se arrepientan antes de caer en vuestras manos. Sabed, en efecto, que Dios es indulgente, misericordioso"; y se han quedado con "A quienes dejen de creer, después de haber creído, y luego se obstinen en su incredulidad, no se les aceptará el arrepentimiento. Ésos son los extraviados" 82.

Rushdie sería un obstinado al negarse a renunciar a la publicación de su obra. Incluso, dos de los imanes que en Gran Bretaña avalaron su conversión en diciembre de 1990, han escrito en mayo de 1991 un manifiesto, preparado por 34 ulemas, en el que reconocen su error anterior y afirman: "Lo que Salman Rushdie ha hecho (abrazar la fe islámica) no ha cambiado el juicio previo de que es un apóstata, pues no ha demostrado un arrepentimiento real y honrado al no convertirlo en buenos hechos".

Como tampoco le ha servido de nada contra la "fatwa" islámica a $\mathrm{Hi}$ toshi Igarashi, traductor japonés de "Versos satánicos", el denunciar por su "total falta de interés" la política del Gobierno japonés hacia el mundo islámico, ni su oposición frontal a la intervención económica de su país en favor de la fuerza multinacional durante la guerra del Golfo.

Pudiera ser, como dicen algunos, que la mejor forma de combatir el integrismo fuera ir introduciendo las libertades sociales y políticas en los países árabes y conceder una ayuda masiva al Norte de Africa para que pueda fijar su población y remansar el integrismo ${ }^{83}$. Respecto al apoyo que pueda darse al pluripartidismo y a los modos democráticos, ya hemos anotado que, al menos en la actualidad, parece que origina un incremento sustancial en los movimientos fundamentalistas. Las ayudas económicas masivas y desinteresadas podrían ayudar a vencer el sentimiento de hostilidad y humillación ante Occidente, pero tendríamos que preguntarnos si estamos dispuestos a darles esas ayudas “desinteresadas", y si más bien no parecería una forma cortés de evitarnos el problema de las inmigraciones masivas. No se trata de cuestionar la validez de la cooperación económica, sino la forma de "venderles" la idea. La población árabe, mayoritariamente joven, ve en el "igualitarismo justiciero" que pregonan los islamistas una respuesta social y económica a sus carencias.

82 El Corán, $5^{34} ; 3^{90}$.

83 Cfr. Sanmarti, Josep M., Islam: la voz de Alá retumba en Occidente, en Caritas, noviembre 1990 , pp. 11-14. 
El premio Nobel de Literatura, el egipcio Naguib Mahfuz, propone: "Redoblar nuestro esfuerzo para propagar el espíritu de nuestra religión en las nuevas generaciones, a través de la educación, y entre toda la gente, por los medios de comunicación, y que se hinque en lo más hondo de sus conciencias, como energía que potencie la piedad hacia Dios y hacia el prójimo, el obrar y el saber, la tolerancia y el respeto de los derechos humanos" 84 .

De una u otra forma, Europa tendrá que aprender a vivir con el islam, y a aceptar un pluralismo cultural, racial y religioso. Y cuanto antes lo haga mejor. Si, comó algunos defienden, la cultura occidental a diferencia de otras culturas, nunca ha sido racista en sus principios, y ha condenado como lacra social las prácticas xenófobas que se han dado en su seno, tiene una oportunidad inmejorable de demostrarlo. Será urgente crear una "cultura de la paz" como necesario reemplazo histórico de la predominante cultura de la guerra. De lo que sí se puede estar seguro es de que el integrismo islámico no se puede detener con los ejércitos. Hoy como ayer, las ideas no se pueden combatir a cañonazos.

\section{LA GUERRA DEL GOLFO PERSICO}

Una parte mayoritaria de los cientos de millones de musulmanes han vivido la guerra "de los 40 días" como "la primera guerra mundial de las culturas", en la que la cultura islámica está siendo derrotada y humillada por el imperialismo de Occidente 85 .

Esta guerra ha provocado una conmoción comparable a la instauración de la República Islámica en Teherán: la esperanza, o el temor, de una revolución populista, neo-islámica, con vocación planetaria, destinada a restaurar un "orden justo", regido por la Ley islámica. Los orígenes filosóficos de esta formidable aventura son tratados en forma pormenorizada por Henry Corbin ${ }^{86}$.

La obra de Xavier Raufer 87 ofrece la primera síntesis internacional de un proceso histórico mayor para la estabilidad de los Estados árabes, la seguridad Europea, las relaciones entre Occidente y el Islam, y el futuro mismo de la civilización islámica.

De este documento excepcional se desprenden algunas evidencias:

84 Mahfuz, Naguib, Puntos de vista, en Diario 16, 30-9-1989.

85 Una exposición concisa sobre las causas inmediatas, tanto político-estratégicas como económicas, de la guerra del Golfo puede verse en Perez AlCALA, Gabriel Ma ${ }^{\mathrm{a}}$, Los orígenes del conflicto del Golfo, en Revista de Fomento Social 183 (1991) 233-247.

86 Cfr. Corbin, Henry, Historia de la Filosofía islámica.

87 Cfr. Raufer, Xavier, Atlas Mondial del l'Islam activiste. La Table Ronde. 
1) La primera evidencia es simple y brutal: la revolución islámica es un proyecto político, bien implantado en los países con mayorías o minorías islámicas (21 países de la Liga Arabe, 28 países en la Africa negra, 19 Estados asiáticos, 6 Estados europeos), y con vocación planetaria.

2) La segunda evidencia es política y cultural: en el proyecto revolucionario islamista las tradiciones shií y sunní (Jomeini y los Hermanos Musulmanes), aunque parten de tradiciones religiosas enfrentadas, se confunden en un solo proyecto revolucionario, presentado como una "alternativa" contra la corrupción, la ignorancia, la injusticia que representan, al mismo tiempo, Occidente y la práctica totalidad de los gobernantes en el poder en los Estados árabes, con las excepciones, quizá, de Gadafi y los dirigentes iraníes 88 .

3) El mensaje religioso islamista despierta entusiasmos y vocaciones a un ritmo apreciable: 3.000 estudiantes anuales en la ciudad santa de Qom en 1978 y 21.000 estudiantes en el 90 .

4) Existe una proliferación de "grupúsculos" revolucionarios y partidos con vocación gobernante que poseen una gran fuerza, como ha demostrado el Frente Islámico de Salvación (FIS), que ganó las elecciones municipales del verano de 90 en Argelia.

5) En términos culturales, finalmente, asistimos a un proceso de restauración que posee múltiples facetas inquietantes: es un germen de guerra civil y religiosa entre musulmanes y una denuncia a Occidente en nombre de una lectura arcaizante de los valores integristas del islam primitivo ${ }^{89}$

El fundamentalismo islámico es un fenómeno cíclico en el orbe musulmán. Basta una chispa política o militar para que prenda la mecha. El desafío de Sadam Husein ${ }^{90}$ y su guerra contra el Goliat occidental tiene ya una

88 La guerra del Golfo ha dividido a las diferentes ramas islámicas. Los escasos partidos shiítas organizados como tales fuera de Irán, se limitaron a seguir la "línea" oficial de "neutralidad" de Teherán, a la espera de ver "pasar por la puerta el cadáver de su enemigo Sadam". La OLP y la Hermandad Musulmana mantuvieron un apoyo incondicional a Sadam; pero, por encima de la "retórica oficial", los integristas sunníes palestinos del Movimiento de Resistencia Islámica o HAMAS, mayoritarios en Gaza, tuvieron que optar por el bolsillo en vez del corazón, ya que quien pagaba era Arabia Saudí y Kuwait. Pero donde las tensiones entre las corrientes islámicas afloraron más visiblemente a causa del conflicto fue en el Magreb, concretamente en Argelia y Túnez.

89 QuiÑONERO, Juan Pedro, El islam y occidente, en ABC, 15-2-1991; ID., Avance de la revolución islámica, en ABC, 23-2-1991.

$90 \mathrm{Si}$ hemos de creer a algunos arabistas, El Libro de las Astucias, de autor anónimo del siglo XIII o comienzos del XIV, traducido al francés por el orientalista de origen árabe René R. Khawam, y que lleva por subtítulo "La estrategia política de los árabes", es el libro de cabecera de Sadam Husein y de otros líderes árabes. En este libro se afirma; "una calabaza es preferible a una cabeza que no contiene ninguna triquiñuela". "Confía más en tu astucia que en tu bravura, y concede más importancia a tu circunspección que a tu coraje en el combate, pues la guerra es una sucesión de acciones para despistar al enemigo". 
primera repercusión innegable: la radicalización de las relaciones entre la Umma islámica y Occidente. Setecientos millones de musulmanes han sentido, con la guerra del Golfo, que la distinción más acusada entre "nosotros" y "ellos" no es la miseria frente a la opulencia, la democracia frente a la dictadura, sino la conciencia religiosa frente al materialismo descreído que advierten en Occidente y que tiene, según ellos, la revolución industrial como norma única de conducta, y ve a los países árabes sólo como fuente de mano de obra barata para los países ricos 91 .

La "internacional islámica" (si así puede llamarse), ante lo que considera como la "adhesión total de Occidente a la cruzada anti-iraquí", "la agresión occidental", está a punto de materializar su primer congreso, en el que buscaría una estrategia de acción política común para la conquista del poder, que obligará a los gobiernos islámicos a adoptar posiciones de enfrentamiento contra el primer mundo, si no desean afrontar revueltas internas de consecuencias imprevisibles. De momento, la comunidad musulmana está hoy cultural, religiosa y diplomáticamente dividida hasta la fragmentación.

La justificación legal de la "Operación Tormenta del Desierto" se basó en el principio de derecho internacional de que a un país no le está permitido invadir a otro y que, en caso que lo haga, hay que obligarle a retirarse, si es preciso con una guerra. Contó también con la legalidad de las decisiones del Consejo de Seguridad de las Naciones Unidas y de la Liga Arabe. Desde esta perspectiva se podría afirmar con Lyotard que "no hay guerras justas, hay sólo guerras "de derecho", es decir, que se desencadenan para defender un derecho" 92.

Pero existen muchas preguntas sin contestar: ¿Ha sido este conflicto armado una guerra del derecho internacional o más bien expresaba la hegemónica voluntad de EE.UU. de arraigarse en una región vital para su eco-

Según Khawam, "la astucia no es sólo un medio de engañar al adversario. Es un arte que constituye la base de toda política". El Libro de las astucias fue escrito casi dos siglos antes que El Príncipe de Maquiavelo

91 Ruiz Montero, P., Daniel Bell: La crisis del Golfo, en ABC, 25-11-1990. Para Daniel Bell, profesor de Sociología de la Un. de Harvard, y pionero de la teoría postindutrial, la crisis del Golfo, será el último enfrentamiento mundial por causas energéticas. "Las nuevas tecnologías, comenta, van a salvar la carencia de recursos creando nuevos componentes".

92 Gianni Baget Bozzo afirma "que los acontecimientos del Golfo son también significativos porque han mostrado que el principio de legalidad internacional debe valer más que el contenido social y político de los Estados protegidos por aquél", en clara referencia a la ausencia de democracia en los regímenes de Kuwait y Arabia Saudí. Cfr. Pacifismo y socialismo, en EL PAIS, 11-4-1991. 
nomía en declive? ¿Q3 ¿Que va a hacer el Consejo de Seguridad con las 197 resoluciones referentes a la cuestión palestina, que ha votado desde 1947 y que jamás han sido aplicadas? ${ }^{94}$ ¿Por qué sí en Kuwait y no en el Tibet, Afganistán, Palestina, Líbano o Chipre? Podría contestarse que alguna vez había que comenzar. Pero ¿por qué precisamente ahora? La respuesta parece ser: aquí, por el petroleo 95; ahora, por el fin de la bipolaridad Este-Oeste. Como ha afirmado Karl Popper, "si Kuwait produjera tapioca" la guerra no habría tenido lugar.

¿Por que no se esperó más tiempo para comprobar la efectividad del embargo económico internacional? Cierto que la concentración de tropas en Arabia Saudí no podría mantenerse durante mucho tiempo, y que puede honradamente dudarse de que las sanciones pudieran reducir por sí solas la capacidad militar de Irak. Pero cabe la fundada sospecha de que la decisión ya estaba tomada con anterioridad. La justificación que se aduce - la de ser una guerra preventiva, con un escenario imaginable, e incluso probable, de un Israel rodeado por el mundo árabe y amenazado nuclearmente, el "defiéndete en los comienzos" de Chamberlain - no está reconocida en .el derecho internacional, y por buenas razones. En todo caso parecen haberse infringido dos principios de la guerra "justa": que se hayan agotado todos los medios no bélicos para la remoción del mal y que el mal que la guerra implica no debe estar en desproporción al mal que se trata de eliminar. Todo ello plantea grandes interrogantes sobre la legitimidad y la inevitabilidad de esta guerra 96.

93 En un reciente artículo Francis Fukuyama, famoso por su trabajo El fin de la historia, argumenta que los futuros Sadam Husein que el mundo engendre habrán de comprender que no existen atajos militares para convertirse en un país moderno, sin posibilidad de evitarse la aburrida tarea del desarrollo económico.

94 Muchos occidentales, como Alain Finkielkraut, consideran que no ha habido una "intervención occidental en el Golfo", sino una justificada reacción a la invasión y absorción iraquí del Emirato de Kuwait. "Ver el conflicto con Irak como una faceta del enfrentamiento Norte-Sur es algo delirante, que exime a Bagdad de todo crimen". Todo lo contrario piensa el argelino residente en Francia Jacques Berque, para el que esta guerra es el primer conflicto armado del Norte contra el Sur y una "respuesta desproporcionada e irresponsable" a la invasión de Kuwait.

95 Algunos opinan que uno de los objetivos de la guerra del Golfo fue mantener el "protectorado" de EE.UU. sobre sus competidores europeos y japoneses, mediante el control de las fuentes del petróleo durante las próximas décadas.

96 Es muy interesante, por su vinculación "oficiosa" con el Vaticano, el largo y sustancioso editorial que dedica el número de Civiltá Cattolica del 17-11-1990 a discutir este problema.

La revista 30 Días, n.2 de febrero de 1991, publica una serie de artículos visceralmente contrarios a la Guerra del Golfo, que se encontraba aún en su fase aérea. Según un reciente informe de la Universidad sueca de Upsala, las guerras de la segunda mitad de este siglo han originado 15 millones de refugiados. La mayor parte de desplazamientos se producen entre países de los mismos "segmentos de penuria". 
Como ha hecho notar Johan Galtung, la guerra como último argumento de fuerza, ha ido evolucionando de su carácter inicial "homicida" - campo de batalla -, al "genocida" - exterminio de amplias poblaciones y minorías étnicas -, y al "ecocida" - destrucción de ecosistemas naturales. Frente a ella, la humanidad debe desarrollar no sólo la "solidaridad sincrónica" (relaciones Norte/Sur en la sociedad de nuestro tiempo), sino también la "solidaridad diacrónica" (relaciones Hoy/Mañana, de los que vivimos hoy, respecto a las generaciones venideras).

En todo caso, el conflicto del Golfo bien pudiera denominarse la guerra de las mentiras. Contra lo que pregonaron las fuerzas multinacionales: "no había ni línea Marginot, ni "bunkers" de hormigón, ni túneles interminables, ni zanjas llenas de petróleo, ni taludes de varios metros de altura; había millares de minas y no millones; no había 500.000 soldados de infantería en Kuwait (en realidad menos de 200.000), ni 150.000 soldados de la Guardia Republicana; no hubo 170.000 prisioneros iraquíes sino menos de 80.000; Ciudad Kuwait no estaba destruida y los rehenes kuwaitíes se cuentan por centenares, no por decenas de miles; (...) las vastas redes terroristas de inspiración iraquí eran una alucinación, no hubo 140.000 apartamentos destruidos por los Scud en Israel (...). La mayoría de los reportajes efectuados en el frente por los "pools" de periodistas constituían un "cebo", según ha reconocido el propio general Schwarzkopf (...). Se ganó a un loco. Queda por vencer la locura, incluida la que no cesamos de alimentar" ${ }^{97}$.

La "brutal represión" de que han sido objeto los kurdos y los shiíes en Irak - con la complicidad implícita iraní y turca -, así como la revancha de Kuwait sobre los "colaboracionistas" palestinos, ilustra perfectamente las carencias de toda solución bélica a una crisis. La situación pone de relieve, además, la extraña interpretación del pragmatismo político que se tiene en Occidente: la coalición internacional que tan contundentemente derrotó a Irak ha mantenido durante meses una fría actitud de neutralidad y silencio en la crisis kurda, y sólo el 6 de abril de 1991, el Consejo de Seguridad de las Naciones Unidas aprobó (sólo con 10 votos de los 15, uno más de los necesa-

97 KAHN, Jean-Fraçois, La guerra no ha tenido lugar y, sin embrago, continúa, en DIARIO 16, 25-3-1991.

Según un informe de la organización ecologista "Greenpeace Internacional", el número de muertos en esta guerra fue de 210.000 , se lanzaron 250.000 bombas ( 6.000 al día), de las que menos del $10 \%$ eran "inteligentes" y, de éstas, un $20 \%$ no alcanzaron sus objetivos. Según esta organización, "nunca antes una sociedad civil había quedado tan destruida y un medio natural tan lesionado". Por ello, Greenpeace ha solicitado en Londres, el 3 de junio de 1991, una Quinta Convención de Ginebra para proteger el medio ambiente durante los conflictos armados. 
rios) la resolución 688 en la que afirma que la represión interna en un país miembro y el éxodo de refugiados como consecuencia de la represión política constituyen "una amenaza para la paz y la seguridad internacional" 98. Sin duda que "la resolución sienta un precedente, pues es la primera vez que movimientos de personas y sus consecuencias son contemplados como una amenaza contra la paz y la seguridad internacionales (...) y situados en la agenda política internacional junto con cuestiones apremiantes como el desarme, las amenazas ambientales, la deuda y la política económica" ${ }^{99}$. La excusa del mantenimiento de la unidad de Irak, deseable, no justifica el genocidio de un pueblo. Este pudiera ser un ejemplo del doble objetivo, del doble rasero, del que.estaría compuesto un nuevo orden internacional 100 . Parece lógicamente absurdo y moralmente grotesco el mantener que las potencias occidentales puedan imponer una serie de condiciones a Irak, que rijan la posesión y desarrollo de armas de destrucción masiva, el carácter de su desarrollo industrial en los próximos años y la disposición de los ingresos de su Gobierno, a la vez que consideran inaceptable la intervención para evitar el genocidio.

Habría que encontrar una correcta relación entre el concepto de soberanía del siglo XVIII, que reclama la no intervención en los asuntos internos de un estado, con el concepto wilsoniano de la autodeterminación étnica, que es uno de los hitos del actual sistema internacional, sin caer en una doctrina de intervención permanente que sería útil, en última instancia, para las naciones agresoras. Pero el pueblo kurdo, formado por unos 20 millones de personas, se encuentra dividido entre Irán, Irak; Siria, Turquía y la Unión Soviética y sus demandas nacionales amenazan los intereses "vitales" de esos cinco países, la mayor parte de ellos ligados a intereses occidentales.

98 La Alta Comisionada para los refugiados, Sadako Ogata ha llamado al éxodo del Golfo Pérsico "el movimiento de refugiados más rápido en los 40 años de historial del ACNUR, y eleva su número a un total de 1.9000.000. Cf. DE Almeida, E. Silva, El éxodo del Golfo Pérsico llevó al extremo los recursos, en Refugiados, 75 (1991) 12-15.

99 Ogata, Sadako, El desafio de los refugiados, en ABC 27-4-1991.

100 Sólo a partir de esta resolución del Consejo de Seguridad, Occidente empezó a enviar ayuda humanitaria al millón setecientos mil kurdos desplazados (más de la mitad niños, en su mayoría menores de diez años), y a construir campamentos de refugiados en las zonas fronterizas con Irán y Turquía. La colaboración de los españoles a través de instituciones como Cruz Roja, Cáritas y otras, ha superado todas las expectativas.

El 15 de abril de 1991, los ministros de Exteriores de la CE, reunidos en Luxemburgo, propusieron al Secretario General de la ONU, que Sadam Husein sea juzgado por "tentativa de genocidio" contra la población kurda, de la que le consideran "personalmente responsable". El 16 de abril, el presidente Bush anunciaba que los gobiernos de la coalición establecerían zonas de seguridad en la parte norte del territorio de Irak, por encima del paralelo 36, para acoger a los refugiados kurdos. 
Ya en el tratado de Sevres de 1920 se había prometido la creación de una región kurda, primero autónoma, después independiente; pero en el tratado de Lausana de 1923 se confirmó el reparto de esa región entre las naciones vecinas y las potencias occidentales.

Ciertamente hay que reconocer que gran parte del debate sobre el problema kurdo es hipócrita. Muchas de las personas que criticaron el uso de la fuerza para terminar con el terror iraquí en Kuwait, están defendiendo ahora que Estados Unidos debería haber continuado la guerra para ayudar a los kurdos.

El mundo árabe, por su parte, permanece indiferente a la tragedia de los kurdos, musulmanes sunníes en su mayoría, por razones tanto culturales como políticas. El pueblo kurdo no es semita, sino de origen indoeuropeo, su lengua pertenece al grupo de las lenguas iraníes, y una autonomía kurda, que sea partícipe en la caída del régimen de Irak, podría ser un factor de desestabilización suplementario en Oriente Próximo.

Sadam y los negociadores kurdos iraquíes han anunciado un acuerdo que establecerá su autonomía sobre un convenio latente suscrito en 1970. Puesto que Sadam incumplió el acuerdo original, sería imprudente fiarse de su palabra. Por esto, la única salida honrosa para el norte de Irak parece estar en una autonomía internacionalmente garantizada por la ONU, que debería ratificar un acuerdo entre Irak y los kurdos que permita a los refugiados volver a sus hogares.

La tragedia del pueblo kurdo y, en menor medida, la de la mayoría shií, ha hecho pasar inadvertido el destino de la minoría cristiana, entre un $5 \%$ y un $14 \%$, sobre todo en el norte de Irak. La minoría cristiana tiene una cultura y una lengua diferente, el arameo, bien en su versión caldea, bien en su versión siríaca, según su pertenencia a una u otra iglesia, y constituye un alto porcentaje de los profesionales y cuadros técnicos del país. De hecho, el médico personal de Sadam Husein y el Ministro de Relaciones Exteriores durante la guerra son cristianos. Aunque la minoría cristiana afirman "no tener problemas con los musulmanes", tienen miedo del futuro, y la tasa de emigración más alta del país. Los obispos no están de acuerdo con que los cristianos se vayan, pero, durante el levantamiento de los kurdos, las iglesias tuvieron que establecer horarios para atender la demanda de certificados de bautismo, "expedidos en inglés".

Estados Unidos tiene una gran tradición política interna, basada en la idea de un Estado democrático de derecho, con sus tres poderes, ejecutivo, legislativo y judicial con bien fundado equilibrio, y un cuarto poder, la prensa, capaz de hacer dimitir a todo un presidente de la nación; pero hacia el exterior frecuentemente ha prevalecido el salvaje Oeste, los propios intere- 
ses, no los derechos humanos. A esta doble política, quizá fuera aplicable la distinción de Max Weber entre una "ética de convicción" y una de "responsabilidad".

En la guerra del Golfo, Estados Unidos ha opuesto al integrismo islámico su "fundamentalismo técnico científico": censura de prensa sin precedentes, cazas "invisibles", armas "inteligentes", guerra "limpia", operación "quirúrgica, efectos "colaterales", misiones de "ablandamiento", "Bagdad iluminada como un árbol de Navidad", etc. Los iraquíes, arrastrados a la aventura por la megalomanía de Sadam, han sido utilizados como cobayas humanas. Basta comparar las bajas en acciones de guerra: 56 norteamericanos, 15 británicos, etc. con las de los 200.000 cadáveres militares iraquíes. Además se ha "satanizado" al adversario: el "nuevo Hitler", ¡la cuarta potencia militar del globo!, posesión de armas biológicas y atómicas,.. Con ello parece justificarse que "son orientales los países en donde cualquier guerra, cualquier genocidio son asuntos puramente locales, y occidentales aquellos en los que la menor efusión de sangre es una tragedia de alcance universal".

Asumiendo la terminología variopinta del sociólogo americano Alvin Toffler, podríamos aseverar que nos encontramos por primera vez en la historia, con lo que él denomina "guerra multiforme" o guerra de la "Tercera Ola", un tipo de conflicto que se corresponde estrechamente con un nuevo sistema para la creación de riqueza.

Vista con ojos occidentales, la guerra del Golfo ha significado para el lider iraquí Sadam Husein 101 la culminación de un total fracaso: ni ha vencido a Irán (1980-1988), ni se ha anexionado a Kuwait, ni ha unido al mundo árabe; ha arruinado y diezmado a su propio pueblo y país, sumergiéndolo en un proceso de guerra civil con el levantamiento de kurdos y shiíes, y ha causado, con el incendio de los pozos de petroleo kuwaitíes, un auténtico desastre ecológico. Según el sueco Berp Bolin, presidente del Panel Intergubernamental del Cambio Climático (IPCC), las emisiones del crudo quemado en los pozos petrolíferos incendiados en Kuwait verterán a la atmófera 10 millones de toneladas de hollín. "No será una catástrofe para el mundo, pronostica Bolin, "pero Kuwait, Irán, Irak e incluso algunos países del océano Indico podrían experimentar efectos muy perjudiciales. Las precipitaciones podrían alterar su curso, y las temperaturas, descender algunos grados, especialmente en la zonas próximas a los pozos en llamas y donde la luz ha sufri-

101 Cfr Mrller, Judith y Laurie Mylroie, Saddam Hussein y la crisis del Golfo. Edit. San Martín, S.L, Madrid 1991. 
do una reducción considerable". Las predicciones de los científicos del Centro de Estudios Meteorológicos del Reino Unido son similares: la reducción de la luz diurna se cifrará en un $99 \%$, y el descenso de las temperaturas durante el día hasta 10 grados centígrados en un radio de 50 kilómetros a partir de los pozos de crudo. Los últimos datos indican que estaban ardiendo 732 pozos en territorio kuwaití ${ }^{102}$. Aunque en un principio se estimó que la operación de extinción de los fuegos duraría hasta marzo de 1992, el día 6 de noviembre de 1991 se ha apagado el último, con un coste de 80.000 millones de dólares, que han ido a engrosar las cuentas de compañías occidentales, en su mayoría norteamericanas, y después de lanzar a la atmósfera 810.000 millones de barriles de petróleo durante los nueve meses que han estado ardiendo.

Sin embargo, a los ojos de las masas árabes, Sadam. Husein, aunque derrotado militarmente, pudiera emerger como el vencedor político de la guerra del Golfo, porque habría tenido un gran proyecto y habría hecho frente a una coalición dirigida por la primera potencia militar mundial, habría atacado, al fin, a Tel Aviv y humillado al Estado Judío "arrogante mustakbir", y habría vendido su imagen de hombre austero y desprendido de las riquezas. A los ojos de buena parte del mundo árabe, Sadam pasaba por ser el nuevo Nasser. El mismo Sadam parecía sentirse el gran líder del mundo musulmán por el simple hecho de poder resistir más de seis días el ataque multinacional, cosa que no pudo hacer una coalición de otras naciones árabes frente a Israel en 1967. Pensar de esta forma y , una vez más, volver a echar sobre Occidente y sobre los "hermanos traidores" toda la culpa del desastre, más que una victoria política de Sadam, sería una derrota de la racionalidad árabe. Pero cuando se desea tanto a un salvador, incluso de tan mala calidad, es que hay un resentimiento muy antiguo. $Y$ consideramos que no se puede aducir que se trata de otra cultura, que explicar a los árabes hasta qué punto fueron engañados por Sadam sería humillarles. Una tal explicación sería racismo paternalista envuelto en antirracismo ${ }^{103}$.

Lo que sí ha conseguido "la madre de todas las batallas" es lo que nunca logró un régimen árabe en el pasado: unir las dos corrientes rivales que tiran del mundo árabe desde hace decenios, el nacionalismo, a menudo autorita-

102 La CE ha aprobado (11-4-1991) la concesión de 200.000 millones de pesetas en créditos para "acabar" con la polución en el Golfo.

103 Juan GoyTisolo, basado en el tiempo que, según la escatología islámica, el fallecido permanece en estado sutil, fluido, separado de la existencia real, pero sin haber entrado del todo en el más allá, nos proporciona una visión literaria de esta guerra, en un libro justiciero, bastante maniqueo y hasta poético en ocasiones (La cuarentena. Mondadori, Madrid 1991). 
rio, modernista, secular, y el integrismo religioso, mesiánico, intolerante y agresivo. Las manifestaciones de solidaridad con Irak en el Magreb, que tanta inquietud han causado en Europa, reflejan no sólo la identificación de las masas con el "nuevo Saladino", vengador de la "arrogancia" occidental e israelí, sino también su repulsa visceral a la destrucción por Occidente de un país de su misma religión, cultura y lengua.

Lo que también ha conseguido es la ralentización del proceso de integración de la CE. Las tensiones internas de los Doce durante el conflicto se ha traducido en un retraso de los planes de unificación política y monetaria y disenciones tocantes a la creación de un dispositivo militar común. El prestigio europeo, y en especial el francés, en el Magreb ha sufrido un daño difícil de reparar.

Como afirmaba recientemente el "rais" de Egipto, Hosni Mubarak, la guerra del Golfo también "fue un hito en nuestra historia: la creación de una coalición de europeos y norteamericanos con árabes para combatir una agresión supone un cambio evidente" en la experiencia tradicional de las tribus árabes que secularmente guerrearon entre sí, pero jamás aceptaron la intromisión extranjera en sus problemas.

Pero en la posguerra, Occidente se encuentra, como un nuevo Ulises, entre Scylla y Charybdis. Si el dictador de Bagdad se mantiene, aunque sea a trancas y barrancas, en el poder, Irak se transformará en santuario privilegiado de terroristas y opositores cuyos objetivos serán las "monarquías corruptas" de la península arábiga, los "regímenes traidores" de Egipto y Siria y los "imperialistas" occidentales. Si, por el contrario, cae Sadam, el mosaico de una oposición fraccionada no podrá resistir el empuje del islamismo y, con toda probabilidad, se instalará en Irak una segunda república islámica al estilo del Irán de Jomeini ${ }^{104}$. Ante esta perspectiva, cabe la posibilidad de que Occidente se zambulla en la paradoja tragicómica de verse obligado a sostener a Sadam, su enemigo público número uno, frente al riesgo de un nuevo foco de contagio fundamentalista. En todo caso, la caja de Pandora se ha abierto para shiíes, sunníes y kurdos. Para estos últimos, George Bush ha pasado de ser "el Sabio", a "el que nos ha abandonado".

El presidente Bush habla de instaurar un "nuevo Orden Internacional" basado en una "estructura regional de seguridad colectiva", aunque nadie parece saber bien en qué consiste. Si no se consigue acabar con el sistema de dominación "colonial" y obtener un reparto más justo de recursos y poderes

104 Los shiíes son el $54 \%$ de la población de Irak, unos nueve millones de personas asentadas en Bagdad y todo el sur de la nación, en especial Basora, Karbala y Najaf. En Kuwait la minoría shií alcanza alrededor del $30 \%$ de la población. 
en el mundo, fruto de un diálogo sobre los derechos y razones de todos los pueblos y no de un monólogo de la ley del más fuerte, se trataría más bien de un nuevo acuerdo global alcanzado entre los de siempre, y el imperio basado en la "pax americana" prolongaría su agonía. Jean Baudrillard habla de un "nuevo orden mundial consensual y televisual a la vez", con un "consenso como grado cero de democracia y la información como grado cero de opinión". "La apuesta crucial - afirma este autor - es la reducción consensual del Islam al orden mundial. No se trata de destruirlo, sino de domarlo, por cualquier medio: la modernización, aunque sea militar, la politización, el nacionalismo, la democracia, los Derechos del hombre, cualquier cosa que pueda electrocutar las resistencias, el reto simbólico que el Islam significa para todo Occidente". Sadam "incluso a lo largo de la guerra contra Occidente ha cumplido su función de domesticación de un Islam que le trae sin cuidado" ${ }^{105}$. Frente a este pesimismo, la Conferencia Internacional de Paz para el Medio Oriente, iniciada el 30 de octubre en Madrid, puede significar un rayo de esperanza.

Desde una perspectiva humanista y cristiana, se necesitaría pasar de una "lógica del egoísmo" a una "lógica de la solidaridad". Roger Garaudy, incluso, habla de que esta guerra podría ser "sólo el preludio de un conflicto bélico de cien años entre los Países del Norte y el Sur. El antiguo "equilibrio del terror" entre el Este y el Oeste se ha convertido en un desequilibrio del terror entre Norte y Sur. El nuevo orden internacional es la agravación del peor y antiguo desorden colonial, el nuevo colonialismo unificado".

Si la Historia es cíclica, el imperio americano seguirá el mismo destino que hasta hoy han tenido todos los imperios. Pero si la Historia sigue un proceso lineal ascendente e indefinido, pudiera ser que el mundo realmente empezara a ser, por una vez y de verdad, la "aldea global" basada en la justicia, en la democracia y en una economía solidaria. El Club de Roma habló ya en 1976 de la creación de un nuevo orden internacional, de la "Primera Revolución Global", que afecta a todos los órdenes de la vida "y que pone en cuestión desde la seguridad alimentaria del planeta hasta la ecología o salud del hábitat", todo ello sustentado en una "ética creativa y solidaria" 106. La encíclica "Centesimus Annus" del Papa Juan Pablo II, que pone en el hombre, en los derechos humanos y en la democracia las realidades que deben moldear la economía y no viceversa, pudiera ser una aportación de la Iglesia Católica a ese nuevo orden.

105 BAUDRILlaRD, Jean, La guerra del Golfo no ha tenido lugar. Anagrama, 1991.

106 Cfr. Conde Soladana, Pedro, ¿Cómo será el nuevo orden?, en El NORTE DE CASTILLA, 16-5-1991. 
Pero no todo parece caminar en esa dirección, y no sólo en los países desarrollados. Sadam sigue en su puesto, las monarquías del Golfo, incluido Kuwait en manos de la familia Al Sabaj, no se democratizan y la cuestión palestina se pudre. Y si alrededor de la aventura de Vietnam surge una "nueva izquierda" que busca la redención en la liberación personal: el éxtasis de la droga, la maravilla del sexo, la liberación de las minorías étnicas, empezando por la femenina, el antiamericanismo...; después de la guerra del Golfo, la izquierda, al menos en España, recobra parádójicamente algunos elementos que fueron de la derecha en los años treinta: la glorificación del autoritarismo, una actitud conspiracional y la creencia en que existe un mal organizado a nivel planetario que campea sobre la impotencia de un bien absoluto a la espera de redención. E incluso, incluye en su acervo dos elementos nuevos, quizá los más paradójicos, el encanto con las sociedades donde las mujeres han vuelto a velar sus rostro y los integrismos religiosos. Esto, sin mencionar el pacifismo de nuevo cuño que plantea, en el fondo, el problema de si la vida es el valor supremo que hay que salvar a "cualquier" precio ${ }^{107}$.

Una vez más se ha pretendido conducir la práctica política con un lenguaje universalista basado en argumentos de la "razón total": conciencia crítica, pueblo y paz; valores atemporales situados más allá del tiempo y fuera del espacio, que sustituyen a la crítica y al diálogo político, e impiden la razón analítica y el pensar en términos racionales. En política, el universalista es un lenguaje que niega parcelas de razón o razones parciales a los que no se confiesan creyentes en la razón total, que son inmediatamente calificados de vendido al poder, enemigos del pueblo y belicistas.

El lenguaje de la razón total, totalitario en sus implicaciones, se caracteriza además por un notable desdén hacia los hechos: proceso histórico de la formación de los Estados árabes, ideología del partido Baas, enfrentamiento de 10 años entre Irak e Irán, participación siria y egipcia en la guerra, apoyo chino y soviético a las resoluciones del Consejo de Seguridad, etc. "Cuando los hechos, complejos en su origen y aleatorios en sus resultados, tropiezan

107 El diputado en el Parlamento Europeo por el Partido Socialista Italiano, Gianni Baget Bozzo hace referencia al nuevo pacifismo, que se ha presentado como un principio absoluto, y en el que coinciden los grupos posterroristas, lo movimientos ecológicos (los "verdes"), los partidos poscomunitas (PDS) y los católicos fundamentalistas (Comunión y Liberación), que no reconocen a Occidente "como valor". "El Pacifismo - afirma - muestra que puede tener también un destino religioso". Cf. Baget Bozzo, G., Pacifismo y Socialismo, en EL PAIS, 11-4-1991.

Lo que no consideramos admisible es la total descalificación que hace el señor Baget, cuando afirma en otro artículo: "Los integrismos sectarios, episcopales y laicos, siempre llegan a destiempo". 
con la claridad de la razón total, el universalista mira hacia otro lado o, sencillamente, los niega" 108.

\section{EL ISLAM EN ESPAÑA}

Los prejuicios medievales recreados en torno a la confrontación islamocristiana en España y las Cruzadas penetraron el inconsciente colectivo de Occidente de forma muy profunda. No obstante, históricamente España, debido a los ocho siglos de el Al-Andalus musulmán, es depositaria de una hermandad con el mundo árabo-islámico de la que no goza ningún otro país de Europa. El filósofo judío y cordobés Maimónides, el místico sufí Ibn Arabi, de Murcia, y San Juan de la Cruz convivieron en paz hace ocho siglos en nuestro país y coincidieron en un mensaje de amor (Dios es amor), de reverencia y respeto a todo lo creado.

Lo que nosotros hoy denominamos "cultura" se conocía entonces con el nombre de ley: "ley de Mafomat", "ley de Moysén", "ley de Cristo". Cada uno nacía, vivía y moría en una ley. Dicha "ley" implicaba la pertenencia a un grupo étnico, la profesión de un misma fe, el empleo de una lengua materna, el encuadramiento dentro de un estatuto jurídico y social peculiar, y el reconocimiento implícito del derecho de la mayoría social dominante a configurar, según sus propias leyes, la organización básica del Estado y el ejercicio del poder. Esto era un hecho admitido en la España cristiana y en la España musulmana, con independencia de que ambas formaciones políticas mantuviesen entre sí una actitud por lo general de hostilidad. Como afirma Ramón González, "no es posible comprender la existencia de estos grupos diversos desde una perspectiva moderna de nacionalismo, porque entonces prevalecía un sentimiento universalista que se armonizaba bien con el sentido localista". En todo caso, más que en una España cristiana bruscamente islamizada a partir del año 711, hay que pensar en una sociedad "teñida paulatinamente de islamismo".

Las relaciones de musulmanes y judíos con los cristianos se contenían principalmente en el "Fuero Real" y en "Las Partidas". Los mudéjares (musulmanes que vivían en las ciudades cristianas conquistadas) recibieron en Castilla un trato legal similar al que los.musulmanes dispensaban a los mozárabes y judíos en sus tierras. Ciertamente que existe el problema de los esclavos que carecían de derechos y eran considerados como cosas. Había esclavos musulmanes en Castilla y cristianos en Granada, consecuencia de 
las duras leyes de la guerra, que se resumían en el antiguo grito ¡"Vae Victis"!, aunque muchas ciudades se rendían "multis pactionibus interpositis".

No deja de ser curioso el manuscrito de la "Disputatio Abutalid", de Samuel Marroquí, que constituye un caso inédito de diálogo interconfesional en el siglo XI en la Península Ibérica. El manuscrito recoge un curiosísimo diálogo entre un judío y un musulmán. En él, el primero defiende la verdad de la fe cristiana basándose en el Corán, mientras el segundo defiende la verdad de la fe cristiana basándose en el Antiguo Testamento. No obstante, ambos, judíos y árabes conservan la memoria histórica de su expulsión "manu militari" de España, y, según se dice, a las presiones de los primeros se debe, en buena parte, la congelación del proceso de beatificación de Isabel la Católica por no haber respetado la "libertad de conciencia".

La diáspora provocada por la expulsión de los judíos de España en 1492 ocasionó que del orden de 160.000 sefardíes abandonaran la península, instalándose en más de un $80 \%$ en países musulmanes de la cuenca mediterránea. Idéntica dimensión de diáspora tendrá la expulsión de los moriscos españoles en 1609, que alcanzó en torno a un cuarto de millón de personas, y que también emigraron al otro lado del mar, esencialmente a la costa y al interior magrebíes.

Durante el siglo XIX las relaciones de España con el mundo árabe se centraron en el denominado "problema marroquí", y se polarizaron en torno a dos vertientes claramente delimitadas y antagónicas: los africanistas y los aislacionistas. Si para éstos "Africa aparecía amenazante y oscura", para los africanistas, en cambio, "el continente vecino Sur de la Península Ibérica empezó a emerger hacia 1870, como un asidero esperanzador capaz de salvar al país real de su naufragio interior". Al final triunfó la postura africanista que fue "intervencionista", aunque sin llegar a dilucidar el dilema de si "su presencia en el norte de Africa era aventurismo militar (problema colonial) o defensa nacional legítima (problema de fronteras)" ${ }^{109}$. Quizá no se haya superado aún esa dicotomía en el momento actual.

A raíz de la Guerra del Golfo, se han levantado muchas voces solicitando la ayuda inteligente y coordinada de las naciones del Norte del Mediterráneo en favor de los derechos humanos, la democratización y desarrollo económico de sus vecinos magrebíes, para hacer del Mare nostrum un puente y no una trinchera. Como afirma el escritor libanés Amín Maalouf, la "fascinación" que el modelo occidental de democracia y prosperidad despierta en los pueblos árabes, así como el hecho de que ese modelo sea "inabordable" en la propia casa, explica tanto "la frustración que lleva al replie-

109 Morales Lezcano, Víctor, Africanismo y orientalismo español en el siglo XIX. UNEI). Madrid 1990. 
gue integrista" como la decisión de cruzar el Mediterráneo. Si los países de la ribera norte tienen miedo al integrismo islámico y a la afluencia de emigrantes, los del sur viven con terror "la agresión cultural" que les está haciendo perder su identidad. El crecimiento demográfico en la cuenca mediterránea tiende a la inversión de la actual desimetría: los Estados europeos contabilizan el $51 \%$ de la población (190 millones), frente a los Estados árabo-musulmanes que suman un 49\% (185 millones). Pero dentro de tres décadas, se habrán sumado 170 nuevos millones, el $90 \%$ de ellos en el mundo musulmán y solo un $10 \%$ en Europa.

Aunque nuestras "tradicionales relaciones de amistad hipano-árabes" se han quedado frecuentemente en pura fraseología oficial, de alguna forma esta hermandad ha quedado en el imaginario colectivo de sus poblaciones. El Al-Andalus debiera ser presentado como lo que es: un fenómeno propio y compartido de "hispanidad" y "arabidad". Este hecho, así como la derogación por el Gobierno de Madrid (14 diciembre 1968) del edicto de expulsión de los judíos en España dictado por los Reyes Católicos (31 marzo 1492), el reconocimiento oficial de la Comunidad Hebrea de Madrid" (1965), el reconocimiento por España del Estado de Israel (enero 1986), y la asunción de la etapa histórica en que la Península Ibérica fue lugar de convivencia armónica y creativa 110 entre las tres culturas, cristiana, judía y árabe pueden haber hecho posible la elección de Madrid como sede de la Conferencia de Paz para Oriente Próximo (30 octubre 1991). La primera visita oficial de un Presidente de Gobierno español a Israel (2 diciembre 1991) y otros proyectos conjuntos, indican el buen estado de las relaciones presentes hispanoisraelíes.

110 A veces se ha exagerado esa armonía: Abderramán III (912-961), por ejemplo, además de tomar el título de "Principe de los Creyentes", que bien pudiera ser un título religioso honorífico, adoptó también el calificativo de "Quien combate victoriosamente por la religión de Dios".

Ron Barkai, profesor de la Universidad de Tel Aviv, presentó en el Coloquio Internacional del Escorial la tesis de que el diálogo interconfesional se hace más agresivo y apologético con la traducción del Corán al latín, la difusión de los textos hebreos postbíblicos y la influencia de la filosofía y de la lógica en los círculos cultos. Según él, la aparición de la órdenes mendicantes acrecienta el carácter combativo del diálogo, pero quienes darán un giro sustancial a la relación entre las tres religiones serán, entre los siglos XIV y XV, los conversos de una y otra religión: Abdallah el Turgeman, Alfonso de Valladolid, Paulus de Sancta María y Hyeronimus de Sancta Fide, entre otros. "Los conversos sostienen diálogos con miembros de su anterior fe a partir de posturas extremistas y violentas, por escrito y en disputas públicas, como por ejemplo la "Disputa de Tortosa". A nuestro juicio, con frecuencia, al menos en el pasado, la aparición de claras mayorías religiosas es una variable muy importante a considerar en el diálo interconfesional y en la tolerancia: ésta duró mientras las culturas cristiana y musulmana estaban cristalizandose (máxime en el siglo XIII); pero una vez asentadas, ambas se cerraron. Sobre este último aspecto Cf. GLICK, Tomas F., Cristianos y musulmanes en la España medieval, 711-1250. Alianza Editorial. 
En la actualidad existen en España básicamente dos clases de musulmanes: los legales y los ilegales, de acuedo con la ley de extranjería.

El primer grupo, mayormente integrado por profesionales, lo forman unas $\mathbf{1 5 . 0 0 0}$ personas que se mueven dentro de las organizaciones religiosas, la influencia doctrinal de los Hermanos Musulmanes, las grandes mezquitas y las subvenciones de embajadas, como Arabia Saudí y Kuwait. Se debaten entre la ambigüedad de vivir en un país laico, que en sus leyes separa religión y Estado, y la naturaleza del islam que señala que no es propio de los musulmanes ser "servidores de los infieles" ("kufar"). Como afirmaba el jeque Abdul Qadir al Murabitum, con motivo de la II Conferencia de Juristas Malaquíes, celebrada en 1983 en Granada: "el islam es un sistema real únicamente si el islam es soberano. El islam debe gobernar porque es el Gobierno de Alá y de su profeta. El islam es una alternativa que hay que crear en el mundo de hoy".

Los Hermanos musulmanes tienen un peso específico dentro del islamismo organizado español. Este movimiento, fundado en 1929 por el maestro de escuela Hassan al Banna, tiene entre sus fundamentos: el wahhabismo, de tintes puritanos, adoptado en 1744 por la familia real saudí; el elemento ascético "zund" del sufismo 111, y la doctrina islamista de Mawdudi. Todos ellos convergen en su proyecto de Estado verdaderamente islámico. El programa de este movimiento se basa en la aplicación de la ley islámica - "sharía" -; el rechazo de la lucha de clases - opuesto a la solidaridad islámica ("takaful"); el reparto de bienes que, en caso de necesidad, autoriza al pobre a robar al rico; la negativa al préstamo con interés, la igualdad entre el hombre y la mujer, aunque en nombre del Corán se justifique la poligamia y el repudio unilateral de esposas; y "una actitud tremendamente crítica y condenatoria de la civilización occidental" a la que desearían aplicar al pie de la letra las exigencias de la "sharía".

El segundo grupo está constituido por el islamismo ilegal, el "islam autoorganizado", representado en España por unas 200.000 personas que se mueve en los andamios de edificios en construcción, en la recolección agrícola, en los vendedores ambulantes, en oratorios y carnicerías "halal" y en los centros que facilitan la inserción de trabajadores arábigo-islámicos. Este grupo, constituido, además de por españoles "conversos", por estadounidenses, filipinos y magrebíes, desea alejarse de cualquier "dependencia financiadora" y conforman un islam más sociológico y cultural que militante

111 Sobre el tema del sufismo cfr NASR, S. H., Sufismo vivo. Herder, Barcelona 1985; Asın P., M., El islam cristiano. Estudio del sufismo a través de las obras de Abenarabi de Murcia. CSIC, Madrid 1933. 
y, por tanto, más permeable a la cultura occidental, aunque persista en formar a sus hijos según la tradición islámica.

De acuerdo a una encuesta realizada, en enero de 1992, por el Centro de Investigación Islamo-Cristiano Darek Nyumba, que ha efectuado un sondeo entre 1.200 personas, la mayoría de los españoles juzga a la religión islámica retrógrada (59\%), represora de la mujer (70) y fanática $(67 \%)$. Sobre las mismas preguntas, los 162 musulmanes residentes en España consultados, aseguran que el islam es retrógrado ( $47 \%$ ), aunque protector de la mujer (51\%) y tolerante $(74 \%)$.

Un $70 \%$ de los españoles no musulmanes y un $69 \%$ de los musulmanes es favorable a que los lugares de culto islámicos gocen de las mismas ventajas fiscales que los de la Iglesia católica. Mientras que un $84 \%$ de los encuestados no islámicos son favorables a que un pariente próximo -hermanos o hijos-pueda contraer matrimonio con una persona musulmana, (un $54 \%$ no quiere tener un alcalde de religión islámica), en el campo musulmán sólo un $61 \%$ de los encuestados es partidario de los matrimonios mixtos. Para un $77 \%$ de los españoles no musulmanes y un $75 \%$ de los musulmanes consultados, los miembros de esa confesión deberían poder salir una hora antes del trabajo -a recuperar luego- para la comida de Ramadán.

En general, "no existen tantos prejuicios contra el musulmán concreto como contra el islam", a juicio de Emilio Galindo, director del centro de Investigación Islamo-cristiano. Y, en líneas generales, los españoles que responden a la consulta muestran menores actitudes de rechazo frente a los musulmanes, en su mayoría inmigrantes ilegales, que los franceses, tal como quedó de manifiesto en una encuesta realizada por el Instituto Francés de la Opinión Pública (IFOP) en Francia y publicada por el diario "Le Monde" en 1991.

Desde el punto de vista organizativo, existe la Federación Española de Entidades Religiosas Islámicas (FEERI), que se constituyó en 1990, de tendencia promarroquí, financiada por Arabia Saudí, y en la que la práctica totalidad de los colectivos son sunníes. Una nueva federación, se constituirá en breve de la mano de Riay Tatari, presidente de la Asociación Musulmana de España, y hasta pudieran llegar a ser cuatro en un futuro no muy lejano. Hasta el momento figuran registradas alrededor de una treintena de asociaciones islámicas en el Ministerio de Justicia, y otras se inscribieron en el Ministerio del Interior. Como dato asociativo a destacar, resulta curioso que mientras Andalucía - con unos 6.000 musulmanes - disponen de 14 asociaciones autóctonas, Cataluña, con unos 40.000, no cuenta con ninguna. Parece que la negociación de los acuerdos entre el Estado español y las 
comunidades musulmanas obligará a las federaciones a una futura confederación.

Según la publicación "Encuentro Islamo-Cristiano", por el momento el islam cuanta con cuatro mezquitas en España y unos 300 oratorios. Las mezquitas, casi todas obras faraónicas, son: la de la M-30, del Centro Cultural Islámico de Madrid, (la mayor de Europa y financiada por el rey Fahd de Arabia Saudí); la de Abu Baker, ubicada en barrio madrileñọ de Tetuán e impulsada por la Asociación Musulmana de España; la de Marbella (financiada por el príncipe Salman de Arabia Saudí); y la mezquita de la Basharat, situada en el kilómetro 32 de la carretera N-IV Córdoba Madrid 112. Desde el punto de vista de la infraestructura de lugares de culto, los musulmanes en España parecen, pues, suficientemente dotados.

CONCLUSIONES.- Si para construir Europa, desde los Urales a las columnas de Hércules, habrá que contar con el "hecho cristiano", una de las principales raíces culturas que la unen e identifican; para construir el mundo árabe musulmán habrá que hacerlo, en similares proporciones, con el "hecho islámico". Y no sólo como realidades culturales "clásicas" ya agostadas, sino atendiendo a la vitalidad ininterrumpida de respuesta trascendente a las grandes preguntas del hombre, que ha mostrado hasta nuestros días. Si sin el cristianismo no se puede entender Europa, sin el islam no se puede comprender la civilización arábigo-musulmana. Y ello, a todos los niveles: político, social y educacional. Para esto, el laicismo deberá dejar de ser una "militancia sectaria y dogmática" y expresar un proyecto de vida regido por la tolerancia.

Teniendo en cuenta las aportaciones que el islam ha hecho a la cultura occidental, por una parte, y el elevado número de musulmanes que viven y, sobre todo vivirán en las naciones europeas, los habitantes de nuestro continente tendremos que prepararnos a fondo para una "cohabitación armoniosa". Además de otras muchas razones, porque el islam no puede detenerse con los ejércitos.

Fieles a una "explicación pluralista", en la que preferimos la "razón analítica" a la "razón universal" y el lenguaje de los hechos al lenguaje universalista, creemos que las variables que han intervenido en el surgimiento del fundamentalismo islámico son múltiples. Son de orden religioso y moral, pero también, de orden ideológico, político, económico, social y cultural. Los

112 Cf. VALLS, Fracesc, Entre fundamentalismo y Ley de extranjería, en EL PAIS, 23-21991. 
países árabes están, en general, formados por sociedades tradicionales, esencialmente rurales y tribales, que han conocido una formidable mutación desde hace medio siglo: demografía (los menores de 20 años representan el $65 \%$ de la población), industrialización, urbanización intensiva, crecimiento de los medios de comunicación, etc. Han tenido que ir adaptándose a un mundo moderno, que vive una aceleración del ritmo de la historia sin precedentes. El gran desafío que, en nuestra opinión, deben afrontar - como lo hizo Europa frente al islam entre el siglo XI y el XVI - consiste en saber integrar en una sana tradición los factores susceptibles de engendrar una sociedad democrática y económicamente moderna. Los problemas del Sur de Europa con los países del Magreb parecen, ser menos ideológicos que sociales y de identidad; de aquí la necesidad de poner en marcha, por medio de políticas euro-árabe-mediterráneas, estrategias no sólo financieras, sino que transfieran tanto la tecnología como su correcta utilización, pues la experiencia de 20 años de "desarrollo" en los países del Sur demuestra que no puede haber progreso sin una mutación cultural de las fuerzas de trabajo. La democracia es indispensable, pero también debe ser aplicada en las relaciones internacionales.

Sin aceptar la tesis de que el islam deba ser "domado o domesticado" para su "reducción consensual al orden mundial", no parece descabellada la tesis de Roger Garaudy de que esta religión necesita también una "teología de la liberación" que le "sirva para que su lucha sea no sólo moral y una llamada a la reflexión personal, sino para que cada musulmán "exija paralelamente transformaciones económicas y políticas, y su credo deje de ser un mero instrumento al servicio de príncipes y cortesanos. Aunque la religión que predomina en Occidente pudiera ser el "monoteísmo del mercado del dinero", que es la más integrista de todas las religiones, "porque pretende establecer el bien y el mal a escala planetaria con el arma absoluta de los préstamos y la deuda", no deja de ser peligroso que el islam mire a Europa como un conjunto de países materialmente ricos, pero espiritualmente pobres, y por tanto necesitados de islamización. A nuestro juicio, la reciprocidad en las relaciones, sobre todo pensando en el proselitismo, que le pide el Sínodo de obispos reunidos en Roma (14-XII-1991) para la "nueva evangelización" de Europa, es razonable.

El islam no puede aceptar el diálogo teológico, pues está ligado a la letra del Corán, del que el musulmán no puede cuestionar ningún artículo, so pena de apostasía. Pero, ¿no podría el islamismo matizar, si no abandonar, su "revelación literalista" en la que, al menos en buena parte, se basa su fundamentalismo? ¿No podrá el islam sufrir una metamorfosis similar a la ope- 
rada en el cristianismo ante el proceso de la secularización? (No secularismo). Su identificación entre religión y poder, la refundación teocrática, el deseo de reislamizar no sólo las tierras del Profeta sino los islotes coránicos de Europa, su proyecto revolucionario de "alternativa planetaria" contra la corrupción, la ignorancia y la injusticia, le colocan en el imposible de querer islamizar la modernidad y no modernizar el islam. El fundamentalismo de Jomeini, la "Yihad", el caso Rushdie, la situación de la mujer, etc., son signos de intolerancia religiosa o denuncian situaciones inaceptables en cualquier sociedad.

En relación con la guerra del Golfo y, en general, con el enfrentamiento secular del mundo arabe-musulmán y Occidente, aceptamos la tesis de Edward Said, para quien el origen del conflicto está en la convergencia entre las "poderosas y anacrónicas ideologías del imperialismo occidental y el nacionalismo árabe". El primero, liderado por Estados Unidos, y siguiendo la larga tradición imperial de franceses y británicos en el siglo XIX, cree sinceramente en su derecho a imponer su voluntad universalmente en nombre de los más nobles principios. El segundo, liderado por Sadam Husein, recoge el coraje anticolonialista, la desesperanza ante la incapacidad para enfrentarse al reto de Israel y la retórica sobre el honor árabe para convertirlos en bandera de enganche. En todo caso, la legitimidad y la inevitabilidad para una guerra "justa" quedan ampliamente cuestionadas en la Guerra del Golfo, para los vencedores y para los vencidos, tanto en su planteamiento "satanizador" como, sobre todo, por sus consecuencias genocidas y "ecocidas" que afectan gravemente a la "solidaridad sincrónica y diacrónica".

Coincidiendo en lo esencial con la tesis de Hans Küng, a nuestro juicio, la tradicional enemistad entre judíos y árabes no es tan tradicional ni está fundamentada, al menos principalmente, en el factor religioso, sino en el nacionalismo moderno que considera a unos y otros como "comunidad de pueblos" que luchan por una misma tierra. Los buenos tiempos de coexistencia árabe-judía podrían permitir concebir también esperanza para Palestina, sobre todo después de la Conferencia de Paz de Madrid. Para medir el camino recorrido hay que recordar de dónde vienen unos y otros: negación de la existencia de un "pueblo palestino" e incluso de la identidad palestina (existen entre cinco y seis millones de palestinos en el mundo), y de hay "que arrojar a los judíos al mar". Pase lo que pase en los próximos meses, o incluso años, el cara a cara de Madrid pudiera constituir un punto sin retorno. La exagerada alegría y los ramos de olivo con que los palestinos han recibido a sus delegados en la Conferencia de Paz de Madrid pudieran crear excesivas expectativas y subsiguientes descontentos. Pero puede tam- 
bién ayudar a convencer a muchos israelíes escépticos de que buena parte del pueblo palestino está a favor de la paz. Si Ben Gurión pudo afirmar que el Estado de Israel se fundamentaba en el "derecho moral del sufrimiento", en nuestra opinión, este es un título que el pueblo palestino se ha ganado con creces. El reconocimiento oficial, por parte del Partido Laborista israelí en su V Congreso, de unos "derechos nacionales" palestinos, así como la aceptación, tanto de la necesidad de que Israel llegue a "compromisos territoriales" con todos sus vecinos árabes, como de la urgencia de "congelar" los asentamiento de colonos judíos en los territorios ocupados, pudieran indicar que nos encontramos en el buen camino, aunque las conversaciones de Washington no ofrezcan avances positivos.

En la confrontación entre el mundo islámico y occidente no nos encontramos ante un "diálogo entre dioses" ni en una "guerra entre dioses" sino en un enfrentamiento entre culturas muy distintas y de difícil diálogo entre ellas. El factor religioso es sólo uno de los ingredientes. Para dialogar entre sí deberán aceptar que hablan del Absoluto, pero sin poseerlo. Quizá pudiera ser verdad aquello de que "son suficientemente religiosos para odiarse y no lo bastante para amarse". Las descalificaciones globales: el islam no ha dado ni libertad, ni bienestar, ni progreso a los pueblos, y jamás se ha visto a un intelectual árabe movilizarse por una causa no árabe, como piensan la mayoría de los occidentales; y considerar a Occidente como una conspiración de fuerzas ocultas que depravan sus costumbres y les reducen a la esclavitud política y cultural, como piensan muchos árabes, no es más que una muestra de la "razón total".

No sólo en nombre de los dioses, sino en nombre de las ideologías, religiosas, ateas o agnósticas, en nombre de los fundamentalismos técnico- científicos actuales, y en nombre de la humanidad, la democracia, el anticolonialismo, el pacifismo y el indigenismo y de la misma defensa del hombre, se han cometido atrocidades en muchos momentos de la historia humana, sin excluir la presente. Es necesario ir creando culturas de paz, respeto y diálogo y pasar de una lógica del egoísmo a una lógica de solidaridad.

Florentino RUBIo C. 